University of Nebraska - Lincoln

DigitalCommons@University of Nebraska - Lincoln

Papers in the Earth and Atmospheric Sciences

Earth and Atmospheric Sciences, Department

$5-2008$

\title{
The Lower Permian Wasp Head Formation, Sydney Basin: High- latitude, shallow marine sedimentation following the late Asselian to early Sakmarian glacial event in eastern Australia
}

\author{
Michael C. Rygel \\ University of Nebraska-Lincoln, rygelmc@potsdam.edu \\ Christopher R. Fielding \\ University of Nebraska-Lincoln, cfielding2@unl.edu \\ Kerrie L. Bann \\ Ichnofacies Analysis Inc., Calgary, $A B$ \\ Tracy D. Frank \\ University of Nebraska-Lincoln, tfrank2@unl.edu \\ Lauren Birgenheier \\ University of Nebraska-Lincoln \\ See next page for additional authors \\ Follow this and additional works at: https://digitalcommons.unl.edu/geosciencefacpub \\ Part of the Earth Sciences Commons
}

Rygel, Michael C.; Fielding, Christopher R.; Bann, Kerrie L.; Frank, Tracy D.; Birgenheier, Lauren; and Tye, Stuart C., "The Lower Permian Wasp Head Formation, Sydney Basin: High-latitude, shallow marine sedimentation following the late Asselian to early Sakmarian glacial event in eastern Australia" (2008). Papers in the Earth and Atmospheric Sciences. 98.

https://digitalcommons.unl.edu/geosciencefacpub/98

This Article is brought to you for free and open access by the Earth and Atmospheric Sciences, Department of at DigitalCommons@University of Nebraska - Lincoln. It has been accepted for inclusion in Papers in the Earth and Atmospheric Sciences by an authorized administrator of DigitalCommons@University of Nebraska - Lincoln. 
Authors

Michael C. Rygel, Christopher R. Fielding, Kerrie L. Bann, Tracy D. Frank, Lauren Birgenheier, and Stuart C. Tye 
Published in Sedimentology 55:5 (2008), pp. 1517-1540; doi: 10.1111/j.1365-3091.2008.00955.x

Copyright (C) 2008 Michael C. Rygel, Christopher R. Fielding, Kerrie L. Bann, Tracy D. Frank, Lauren Birgenheier, and Stuart C. Tye; journal compilation ( 2008 International Association of Sedimentologists; published by Blackwell/John Wiley.

Used by permission.

Submitted June 2, 2007; accepted after revisions January 7, 2008.

\title{
The Lower Permian Wasp Head Formation, Sydney Basin: High-latitude, shallow marine sedimentation following the late Asselian to early Sakmarian glacial event in eastern Australia
}

\author{
Michael C. Rygel, ${ }^{1}$ Christopher R. Fielding, ${ }^{1}$ Kerrie L. Bann, ${ }^{2}$ Tracy D. Frank, ${ }^{1}$ \\ Lauren Birgenheier, ${ }^{1}$ and Stuart C. Tye ${ }^{3}$ \\ ${ }^{1}$ Department of Geosciences, 214 Bessey Hall, University of Nebraska-Lincoln, Lincoln, NE 68588, USA \\ ${ }^{2}$ Ichnofacies Analysis Inc., 9 Sienna Hills Court SW, Calgary, AB, Canada T3H 2W3 \\ ${ }^{3}$ Husky Energy, 707 8th Avenue SW, Calgary, AB, Canada T2P 3G7
}

Present address for M. C. Rygel - Department of Geology, State University of New York, College at Potsdam, 44 Pierrepont Ave., Potsdam, NY 13676, USA; email rygelmc@potsdam.edu

\begin{abstract}
The Lower Permian Wasp Head Formation (early to middle Sakmarian) is a $\sim 95 \mathrm{~m}$ thick unit that was deposited during the transition to a non-glacial period following the late Asselian to early Sakmarian glacial event in eastern Australia. This shallow marine, sandstone-dominated unit can be subdivided into six facies associations. (i) The marine sediment gravity flow facies association consists of breccias and conglomerates deposited in upper shoreface water depths. (ii) Upper shoreface deposits consist of cross-stratified, conglomeratic sandstones with an impoverished expression of the Skolithos Ichnofacies. (iii) Middle shoreface deposits consist of hummocky cross-stratified sandstones with a trace fossil assemblage that represents the Skolithos Ichnofacies. (iv) Lower shoreface deposits are similar to middle shoreface deposits, but contain more pervasive bioturbation and a distal expression of the Skolithos Ichnofacies to a proximal expression of the Cruziana Ichnofacies. (v) Delta-influenced, lower shoreface-offshore transition deposits are distinguished by sparsely bioturbated carbonaceous mudstone drapes within a variety of shoreface and offshore deposits. Trace fossil assemblages represent distal expressions of the Skolithos Ichnofacies to stressed, proximal expressions of the Cruziana Ichnofacies. Impoverished trace fossil assemblages record variable and episodic environmental stresses possibly caused by fluctuations in sedimentation rates, substrate consistencies, salinity, oxygen levels, turbidity and other physiochemical stresses characteristic of deltaic conditions. (vi) The offshore transition-offshore facies association consists of mudstone and admixed sandstone and mudstone with pervasive bioturbation and an archetypal to distal expression of the Cruziana Ichnofacies. The lowermost $\sim 50 \mathrm{~m}$ of the formation consists of a single deepening upward cycle formed as the basin transitioned from glacioisostatic rebound following the Asselian to early Sakmarian glacial to a regime dominated by regional extensional subsidence without significant glacial influence. The upper $\sim 45 \mathrm{~m}$ of the formation can be subdivided into three shallowing upward cycles (parasequences) that formed in the aftermath of rapid, possibly glacioeustatic, rises in relative sea-level or due to autocyclic progradation patterns. The shift to a parasequence-dominated architecture and progressive decrease in ice-rafted debris upwards through the succession records the release from glacioisostatic rebound and amelioration of climate that accompanied the transition to broadly non-glacial conditions.
\end{abstract}

Keywords: cyclothem, Gondwana, ice house, ice-rafted debris, late Paleozoic ice age, trace fossil 


\section{Introduction}

The Permian succession of the southern Sydney Basin has long been regarded as preserving a record of the late Paleozoic ice age (most recently Dickins, 1996; Tye et al., 1996; Eyles et al., 1997, 1998; Fielding et al., 2006). Features of the succession that are persuasive in this regard include: (i) an abundance of outsized, extraformational clasts up to $2 \mathrm{~m}$ in diameter encased within fine-grained marine mudrocks (Thiele, 1903; Gostin, 1968; Gostin \& Herbert, 1973); (ii) abundance of enigmatic pseudomorphs termed "glendonites" known to have replaced the calcium carbonate hexahydrate mineral ikaite, which typically forms on cold, oxygen-starved, sea floors (Carr et al., 1989); (iii) the low-diversity but often highabundance marine invertebrate fauna (Dickins et al., 1969) typified by the thick-shelled bivalve Eurydesma (Runnegar, 1979; and, more locally, (iv) soft-sediment deformation structures that have been interpreted as iceberg keel turbates (Eyles et al., 1997). Despite a general consensus that the succession was formed in a "glacially influenced" marine setting, the resolution of component glacial advance-retreat cycles or glacial to non-glacial cycles has thus far proved elusive and no firm conclusions have been drawn by recent studies (Eyles et al., 1998).

Historically, most reviews of the late Paleozoic ice age have asserted or assumed that it was a single, long-lived event tens of millions of years in duration, perhaps with some internal cycles of waxing and waning (Figure 1; Veevers \& Powell, 1987; Frakes \& Francis, 1988; Crowley \& Baum, 1991, 1992; Frakes et al., 1992; Crowell, 1999). Other workers have, however, suggested that the late Paleozoic ice age consisted of discrete glacial periods (10 to $20 \mathrm{Myr}$ ) separated by non-glacial periods of similar duration (e.g. Isbell et al., 2003). Recent research (Jones \& Fielding, 2004; Montañez et al., 2007; Fielding et al., 2008) suggests that the record of late Paleozoic glaciation in eastern Australia consists of a number of even shorter (1 to $8 \mathrm{Myr}$ ), discrete glacial intervals separated by non-glacial periods of similar duration. This interpretation is consistent with paleo-temperature and paleo- $p \mathrm{CO}_{2}$ proxy records from the Carboniferous and Permian paleo-equatorial realm (Montañez et al., 2007). The new vision of a late Paleozoic ice age consisting of multiple, major cycles that appear to be recorded globally raises the issue that the glacial to non-glacial cycles ought to be recognizable stratigraphically, in addition to various other, perhaps short-term (Milankovitch-scale?), stratigraphic cycles.

The stratigraphic signature of the 1 to $8 \mathrm{Myr}$ glacial events noted above is complex in the marine Permian record of Australia, with a general lack of clear, large-scale cyclicity that can be interpreted in terms of glacial advance and retreat. Four such longterm deglaciation cycles have been well-documented in southern Africa, however (Visser, 1997; Visser et al., 1997; Bangert et al., 1999; Stollhofen et al., 2000). Short-term, possibly Milankovitch band, cycles have been tentatively recognized in Permian shallow marine strata elsewhere in Australia (e.g. Lever, 2004) and in alluvial plain strata in Antarctica (Fielding \& Webb, 1996) but, as yet, the principal long-term cycles remain largely unresolved. The present study provides a stratigraphic and sedimentological reevaluation of the Wasp Head Formation and documents the presence of possible glacioeustatic cyclicity in this unit.

\section{Tectono-Stratigraphic Framework}

The Sydney Basin of New South Wales forms the southern part of the composite Bowen-GunnedahSydney Basin System (Figure 2), a 2000 km long, north-south elongate depocenter in eastern Australia that records a complex history spanning the Late Carboniferous through to Middle Triassic (Veevers et al., 1994; Fielding et al., 2001). Throughout the basin system, sedimentation initially commenced in a series of discrete extensional basins (for example, in the Hunter Valley of the northern Sydney Basin, where horst-graben topography can be demonstrated: see Glen, 2005 for a review). In the southernmost Sydney Basin, Tye et al. (1996) tentatively interpreted basal, Lower Permian stratigraphic units (Talaterang Group: Figure 3) as having formed in similar, coeval, extensional basins (also see Fielding et al., 2001). The Talaterang Group (<100 m thick) comprises the shallow marine Wasp Head Formation in the south and the predominantly terrestrial Clyde Coal Measures to the west and north (Figure 3; Tye et al., 1996). These Early Permian units were formed when the southern Sydney Basin was $\sim 60^{\circ}$ south of the paleoequator. The overlying Yadboro and Tallong conglomerates, Yarrunga Coal Measures, Pebbley Beach and Snapper Point Formations contain a variety of ma- 


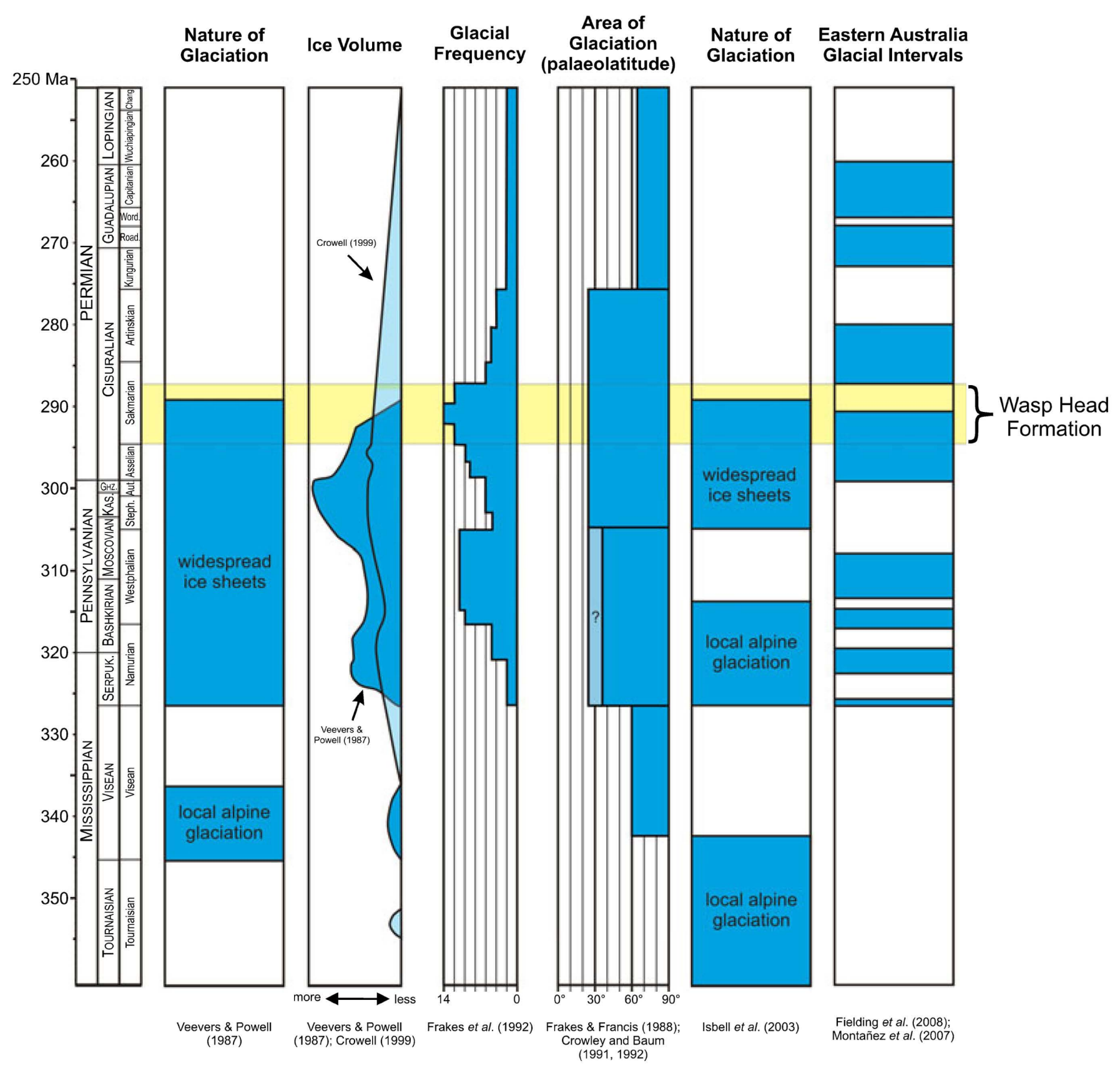

Figure 1. Historical representation of the duration and nature of Gondwanan glaciation [modified from Isbell et al. (2003)] compared with the glacial record of eastern Australia (Montañez et al., 2007; Fielding et al., 2008). Permian time scale from Wardlaw et al. (2004) and Carboniferous time scale from Menning et al. (2000) and Trapp et al. (2004).

rine, terrestrial and basin margin facies formed as the extensional topography filled during a phase of more uniform, regional subsidence (Tye et al., 1996; Fielding et al., 2001). Atop this succession, the Wandrawandian and Berry siltstones record basin-wide transgressive events separated by the shoreface deposits of the Nowra Sandstone. Extrusion of the overlying
Gerringong volcanic facies of the Broughton Formation and Illawarra Coal Measures (Bull \& Cas, 1989) marks the onset of significant volcanism in the basin, coeval with the onset of foreland loading, and eventual transition to predominantly terrestrial sediment accumulation in a retroarc foreland basin (Fielding et al., 2001). 


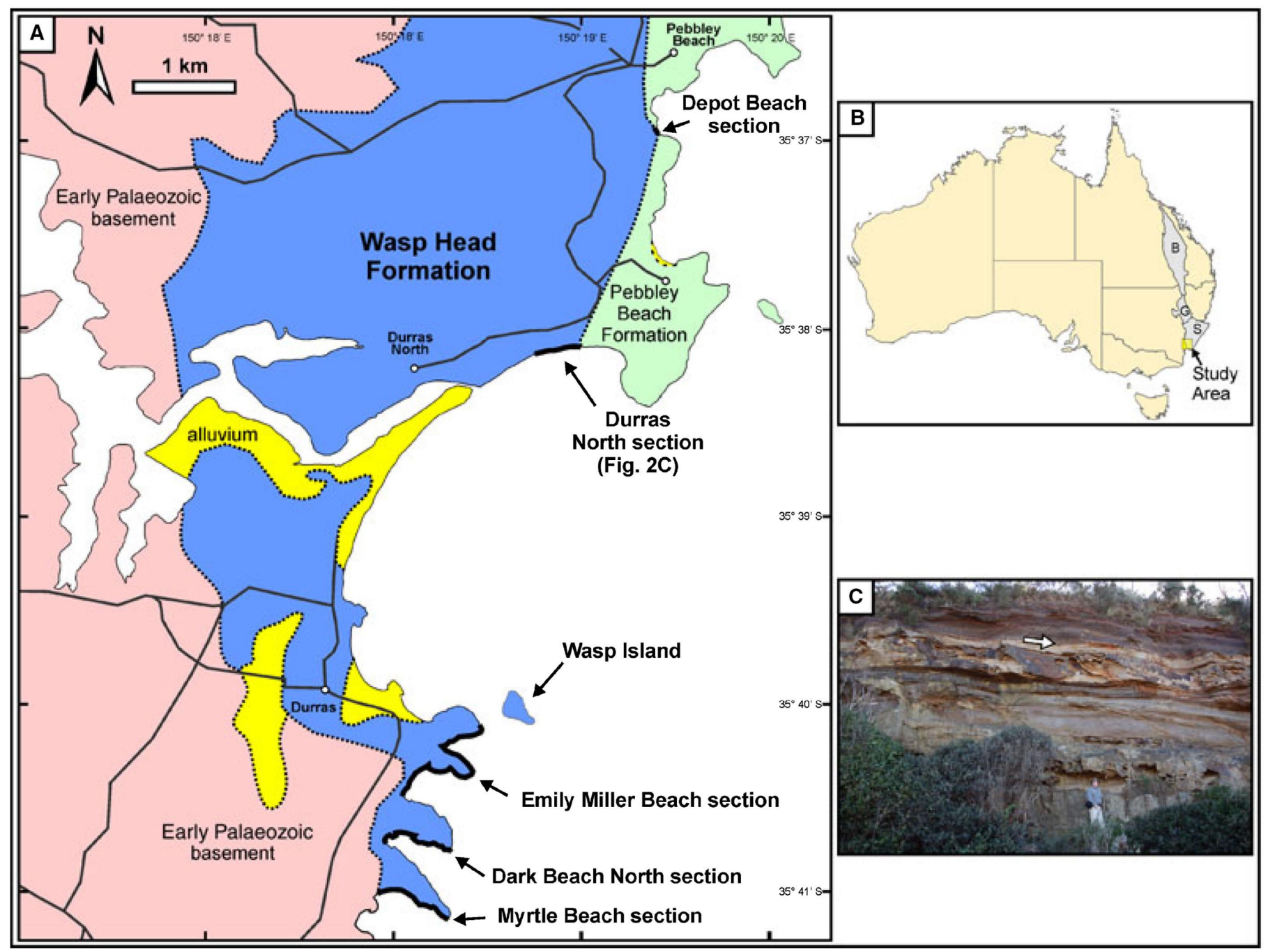

Figure 2. (A) Map showing the spatial distribution of the Wasp Head Formation and the location of the measured sections described in this study. (B) Map showing the location of the southern Sydney Basin. (C) Photograph showing the revised contact (arrow) between the Wasp Head Formation and overlying Pebbley Beach Formation in the Durras North section.

\section{Stratigraphy of the Wasp Head Formation}

The Wasp Head Formation represents the Lower Permian Talaterang Group in coastal exposures between Myrtle Beach and Depot Beach, near the settlement of Durras (Figure 2; Tye et al., 1996). Stratigraphic relationships (Tye et al., 1996) and biostratigraphy (Dickins et al., 1969; Runnegar, 1980; Briggs, 1998) suggest that the Wasp Head Formation and Clyde Coal Measures represent coeval, early to middle Sakmarian strata deposited within a series of small rift basins.

The type section of the Wasp Head Formation contains $\sim 95 \mathrm{~m}$ of section between Emily Miller Beach and Wasp Head (Figures 2 and 4). At its type section, the basal unconformity separates a sedimentary breccia from the underlying metasedimen- tary rocks of the Wagonga Group (Ordovician). The unconformity is also exposed at Myrtle Beach and Dark Beach reference sections, the latter of which is reported to contain glacial striae on the unconformity surface (Gostin, 1968). These features could not be located, presumably because of constant exposure and burial of intertidal exposures during beach profile changes. As many as four sedimentary breccias are present in the basal $25 \mathrm{~m}$ of the formation; these units are interbedded with and pass upwards into a further $\sim 70 \mathrm{~m}$ of sandstone, mudstone, thin conglomerate, and admixed sandstone and mudstone. As defined by Gostin \& Herbert (1973), the Wasp Head Formation continues upsection to the first mudstone (which is actually an admixed sandstone and mudstone formed by intense bioturbation) above the sandstone exposed at Wasp Head (Gostin 


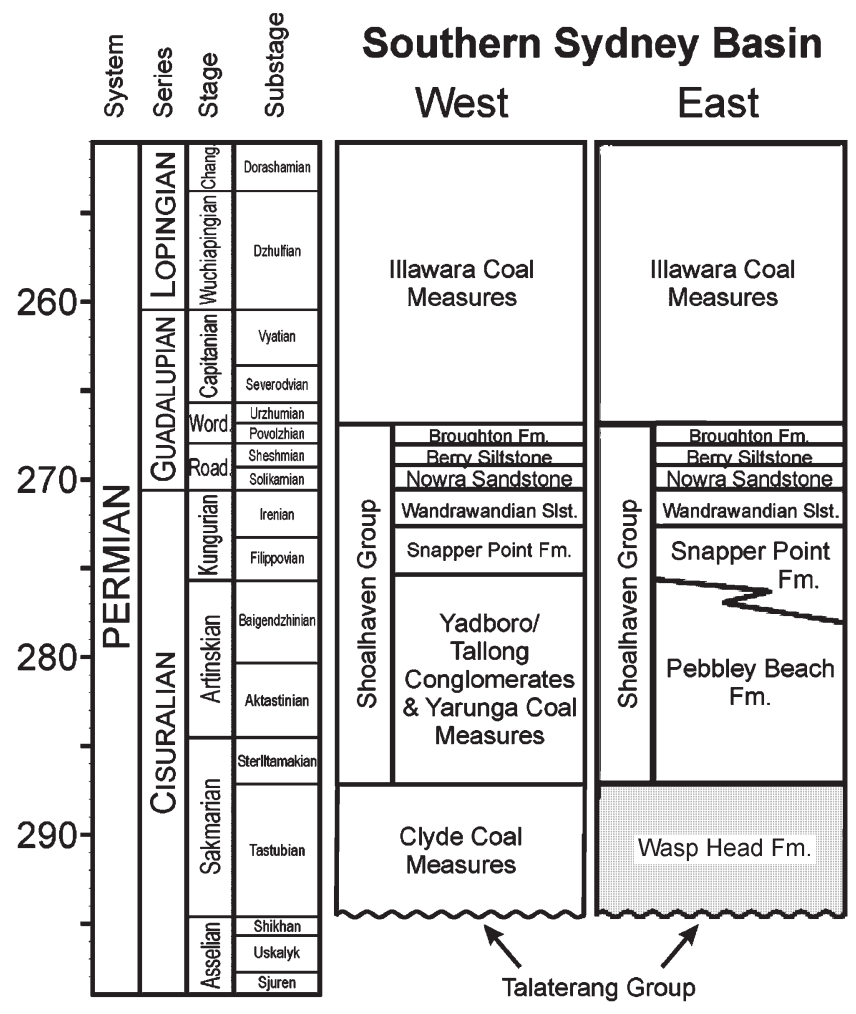

Figure 3. Stratigraphy of the southern Sydney Basin modified from Tye et al. (1996). Permian time scale from Wardlaw et al. (2004) modified to include sub-stages commonly used in eastern Australian biostratigraphy (Briggs, 1998; Foster \& Archbold, 2001).

\& Herbert, 1973). Unfortunately, by this definition the top of the formation is concealed beneath the sea between Wasp Head and Wasp Island (Figure 2). Reference sections at Durras North and Depot Beach also contain the admixed sandstone/mudstone interval, but its basal contact is covered at both locations. In addition to being inaccessible, the presently defined top of the formation is problematic because it is ambiguous, due to there being similar admixed facies in overlying strata (see below).

In the present study the Wasp Head Formation is redefined and the top contact is placed about $11.5 \mathrm{~m}$ higher in the section, at the base of the lowest laminated mudstone in the Durras North and Depot Beach reference sections (Figures 2 and 4), rather than at the unexposed base of the admixed sandstone/mudstone. In addition to being accessible and unequivocal, this surface also represents a regionally traceable transgressive surface that can be used to subdivide the basin fill into units of genetic significance and groups shallowing upward cycles typical of this interval within the Wasp Head Formation.

\section{Previous Studies of the Wasp Head Formation}

Gostin \& Herbert (1973) interpreted the Wasp Head Formation as a shallow marine unit with a coarse-grained, lower part deposited in a stormy, "littoral to sublittoral" environment and a finer-grained upper part deposited in calmer, deeper waters. The majority of the coarse-grained debris in this formation was interpreted as a product of shore ice and river ice. Later authors interpreted the coarse-grained debris in this area as having been glacially derived (Eyles et al., 1997, 1998), a likely scenario given the ubiquity of clasts and the known glacial conditions at this time (Veevers \& Powell, 1987; Isbell et al., 2003; Jones \& Fielding, 2004).

McCarthy (1979) examined the trace fossils of the Wasp Head Formation and concluded that foreshore, open shoreface and protected shoreface environments were represented. Given the ubiquity of hummocky cross-strata, Tye et al. (1996) concluded that protected shoreface environments are not represented in the Wasp Head Formation. Overall, Tye et al. (1996) concurred with the formation-scale trends observed by Gostin \& Herbert (1973) and interpreted this unit as recording two upward-deepening sequences. In an overview of the depositional environments of Lower Permian units in the southern Sydney Basin, Eyles et al. (1998) described selected intervals from the Wasp Head Formation and interpreted them as being deposited in shallow marine environments ranging from inner to mid-outer shelf.

Because descriptions of the Wasp Head Formation provided by Eyles et al. (1998) do not provide comprehensive coverage of the unit, their stratigraphic overview omits important paleoenvironmental, paleoclimatic and relative sea-level changes recorded within this unit. Detailed measured sections of the entire Wasp Head Formation are provided in the present study and serve as the basis for a detailed sedimentological study of this unit. Trace fossil data and ichnofacies analysis have been integrated to enhance the resolution of the paleoenvironmental interpretations. This study provides a wealth of new information about the sedimentological record of the late Sakmarian glacial event in the southernmost Sydney Basin.

\section{Facies Associations}

The Wasp Head Formation can be subdivided into six facies associations based on sedimentologi- 
A

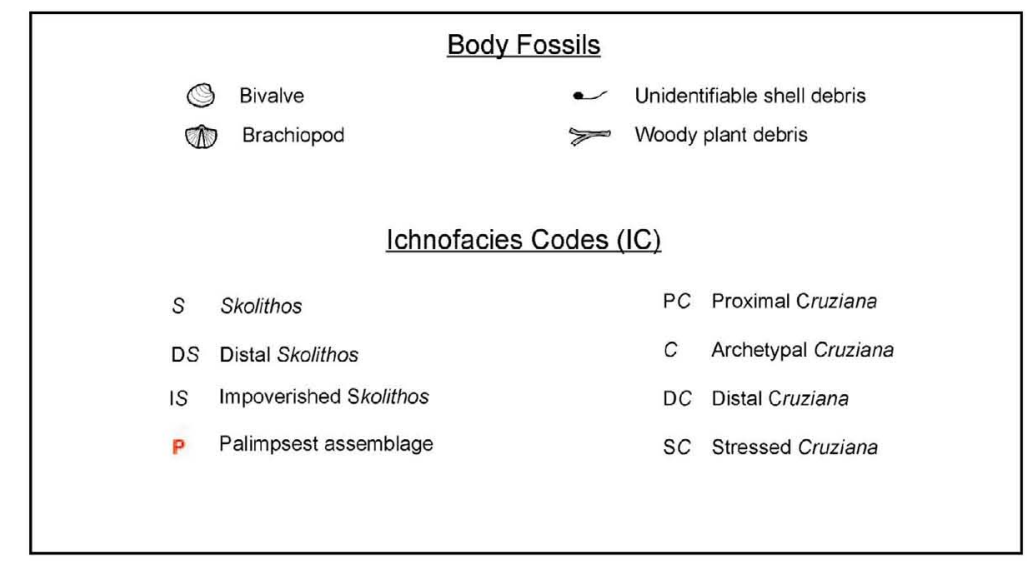

\section{Myrtle Beach}

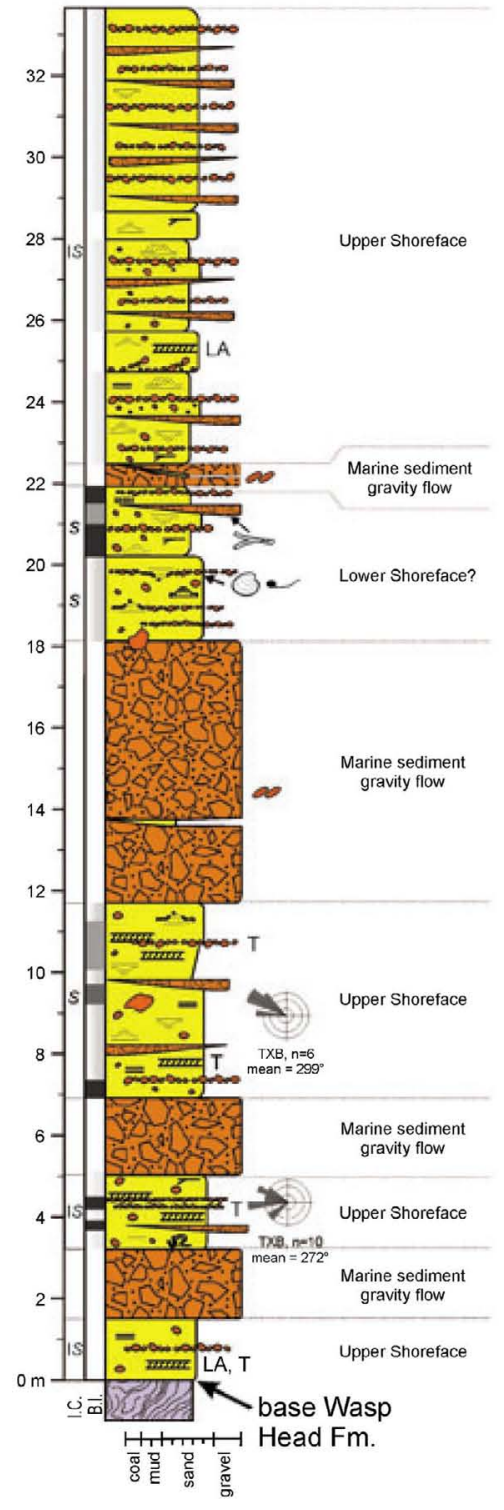

\section{Dark Beach North}

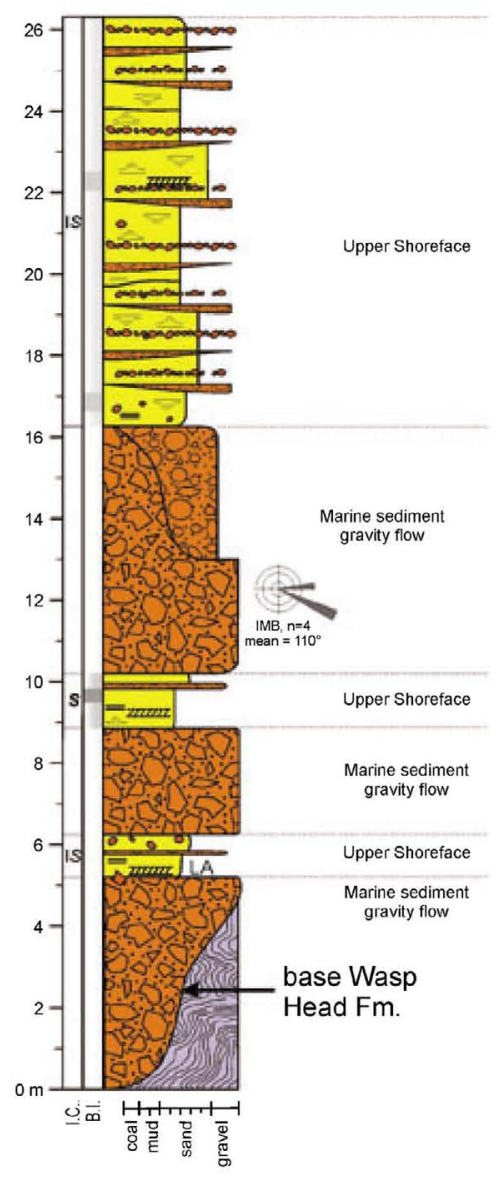

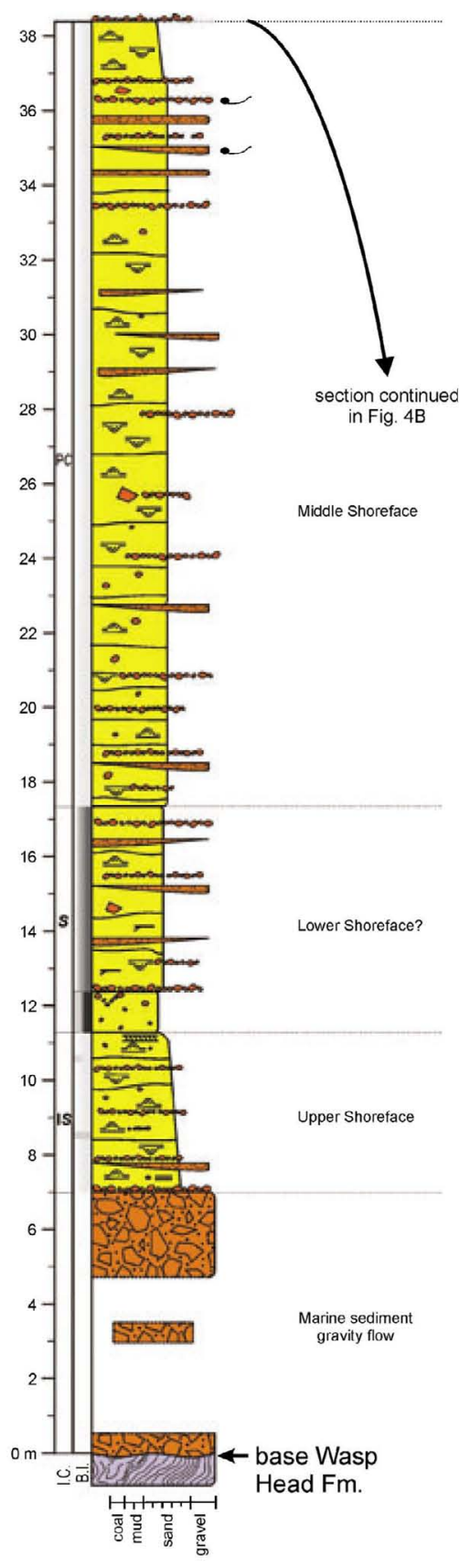

Emily Miller Beach

(lower part)

Figure 4. Measured sections through the Wasp Head Formation: (A) lower part. 


\section{B}

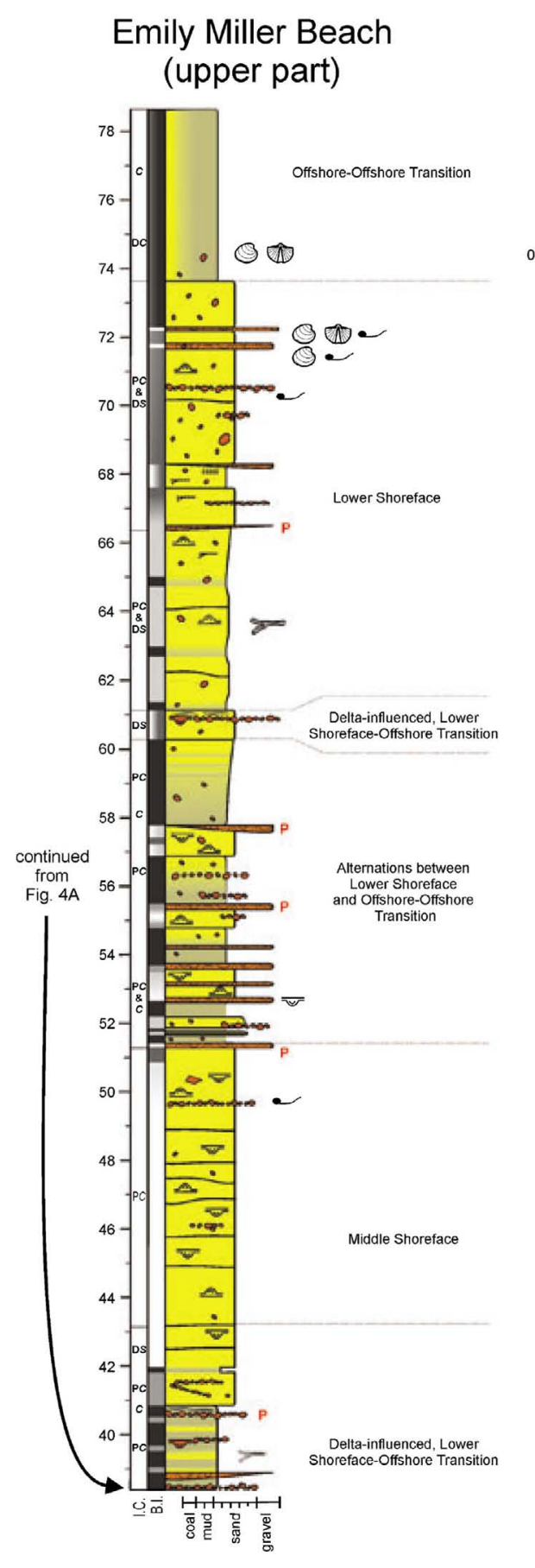

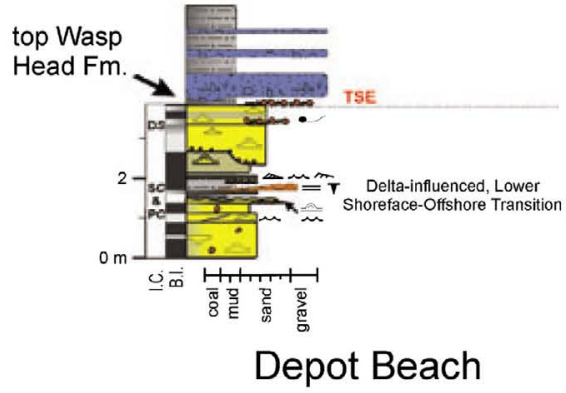

Offshore-Offshore Transition

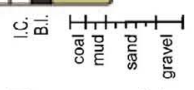

Durras North

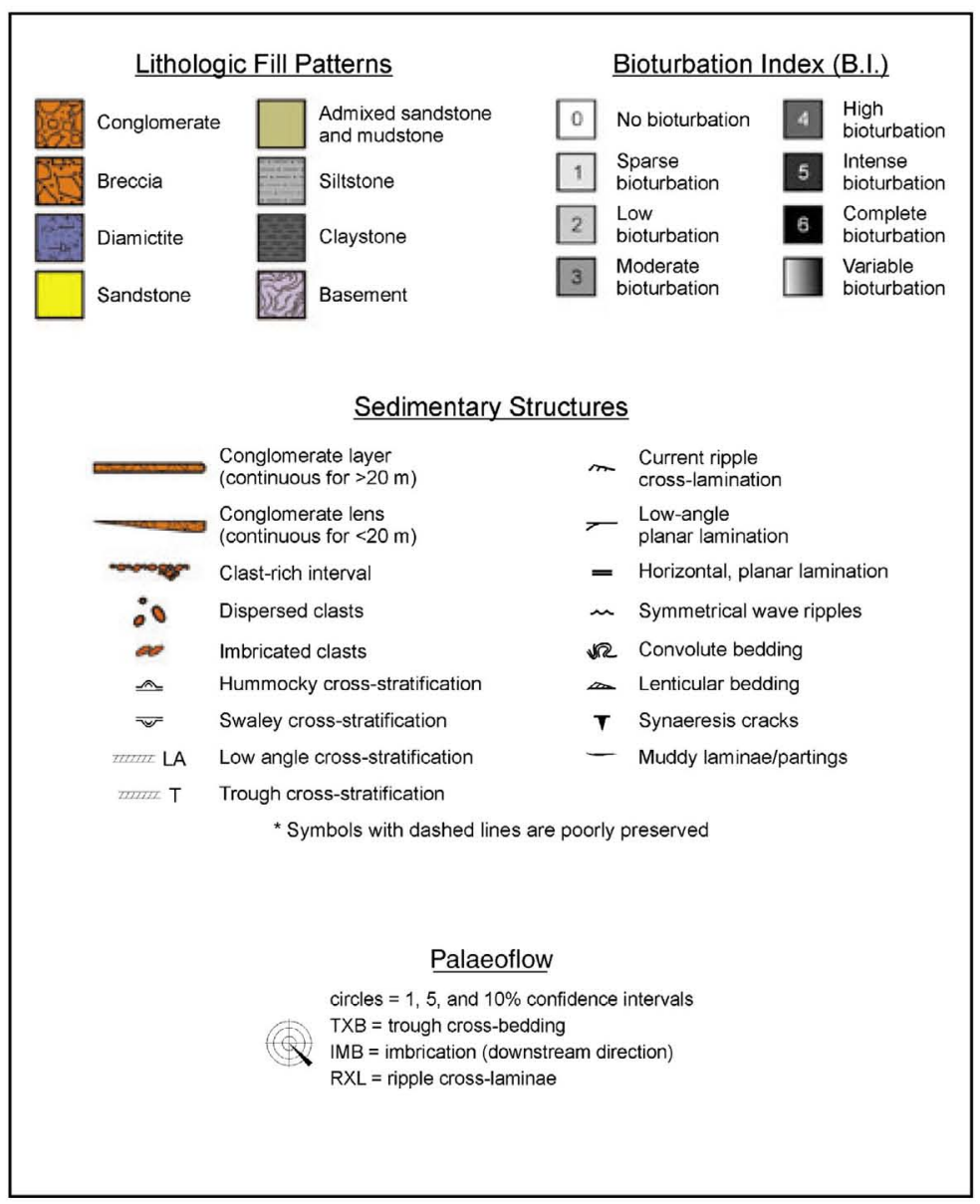

Figure 4. Measured sections through the Wasp Head Formation: (B) upper part. 


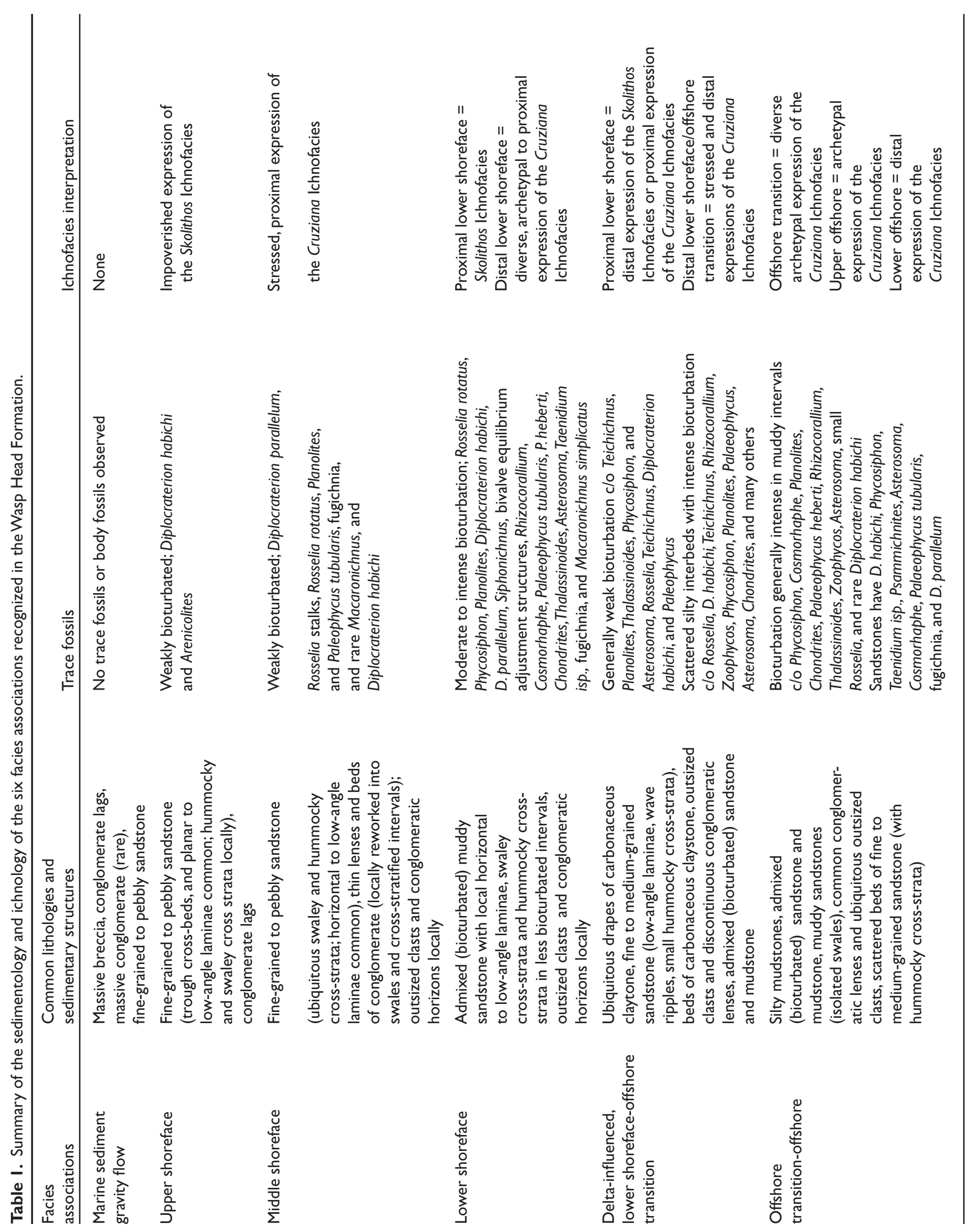




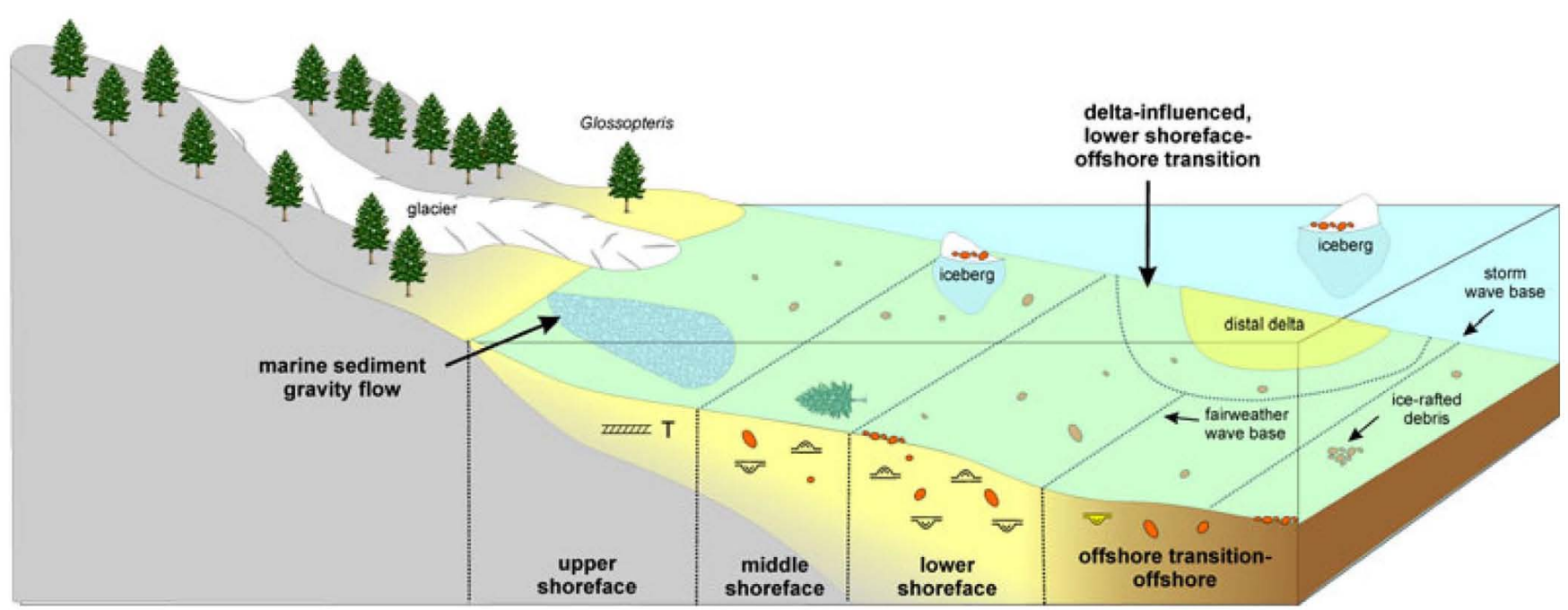

Figure 5. Block diagram showing the spatial relationships between the facies associations in the Wasp Head Formation and their interpreted paleogeographical context. Facies associations are labeled in bold font, symbols for sedimentary structures and features are the same as in Figure 4.

cal and ichnological criteria (Table 1; Figures 4 and 5). Measurement of bioturbation intensity (B.I.) follows the scheme of Bann et al. (2004) which was adapted from Taylor \& Goldring (1993). These facies associations represent deposition in a variety of shallow marine environments from shoreface to offshore water depths.

\section{Marine sediment gravity flow facies association}

\section{Description}

The marine sediment gravity flow facies association occurs in the basal $\sim 23 \mathrm{~m}$ of the Wasp Head Formation and is exposed in the Emily Miller Beach, Dark Beach North and Myrtle Beach sections (Figures 4 and 6). Constituent lithofacies include sedimentary breccia with minor conglomerate and sandstone (Table 1; Figures 4 and 6).

Sedimentary breccias comprise the majority of the marine sediment gravity flow facies association. Individual beds range from 0.20 to $6.05 \mathrm{~m}$ thick, thicken towards the western edge of the outcrop, and have sharp, erosional bases (Figure 6A). Breccias are poorly to very poorly-sorted and supported by angular to subrounded clasts ( $\leq 4 \mathrm{~m}$ in diameter) derived from the underlying metasedimentary basement (Figure 6A). Beds are internally massive except for crude imbrication recording paleoflow to the east (mean $=108^{\circ}, n=20$ ) and locally contain normal grading that passes upwards into thin sandstones (Figure 6B). The lithic sandstone to siltstone matrix comprises $\sim 20 \%$ of the unit. Upper contacts are sharp to sharply gradational over a few centimeters, and the tops of several beds have clasts that protrude upwards and are encased by the overlying lithologies (Figure 6C). Many breccias thin, pass laterally into reworked gravel lags, and/or pinch out towards the eastern edge of the outcrop belt (a distance of $\sim 250 \mathrm{~m}$ ).

Sandstones and conglomerates are only locally present in the marine sediment-gravity flow facies association. Lithic, fine-grained to pebbly coarse-grained sandstones occur as lenses above graded breccias or as partings within the breccias that thicken to the east (Figure 6B). Sandstones atop graded beds have gradational bases and sharp tops whereas lenticular interbeds have sharp top and bottom contacts. Apart from grain-size changes, sandstones are internally structureless and no bioturbation was observed. Some breccias pass gradationally into reworked conglomeratic lags with rare shell debris. At $\sim 16 \mathrm{~m}$ in the Dark Beach North section, a discrete $3 \mathrm{~m}$ thick, erosionally based body of well-sorted, clast-supported, pebble-cobble conglomerate is enclosed within a poorly-sorted boulder breccia. This body of conglomerate has sharp upper and lower (?) contacts, and is lobate in cross-section with a rounded terminus on its eastern edge.

\section{Interpretation}

The interpretation of previous authors that conglomerates and breccias of the Wasp Head Formation represent debris flows that originated on the adjacent basin margins (Gostin, 1968; Gostin \& Herbert, 1973; Eyles et al., 1998) is supported by the observations presented above. Rare shelly horizons and a close 

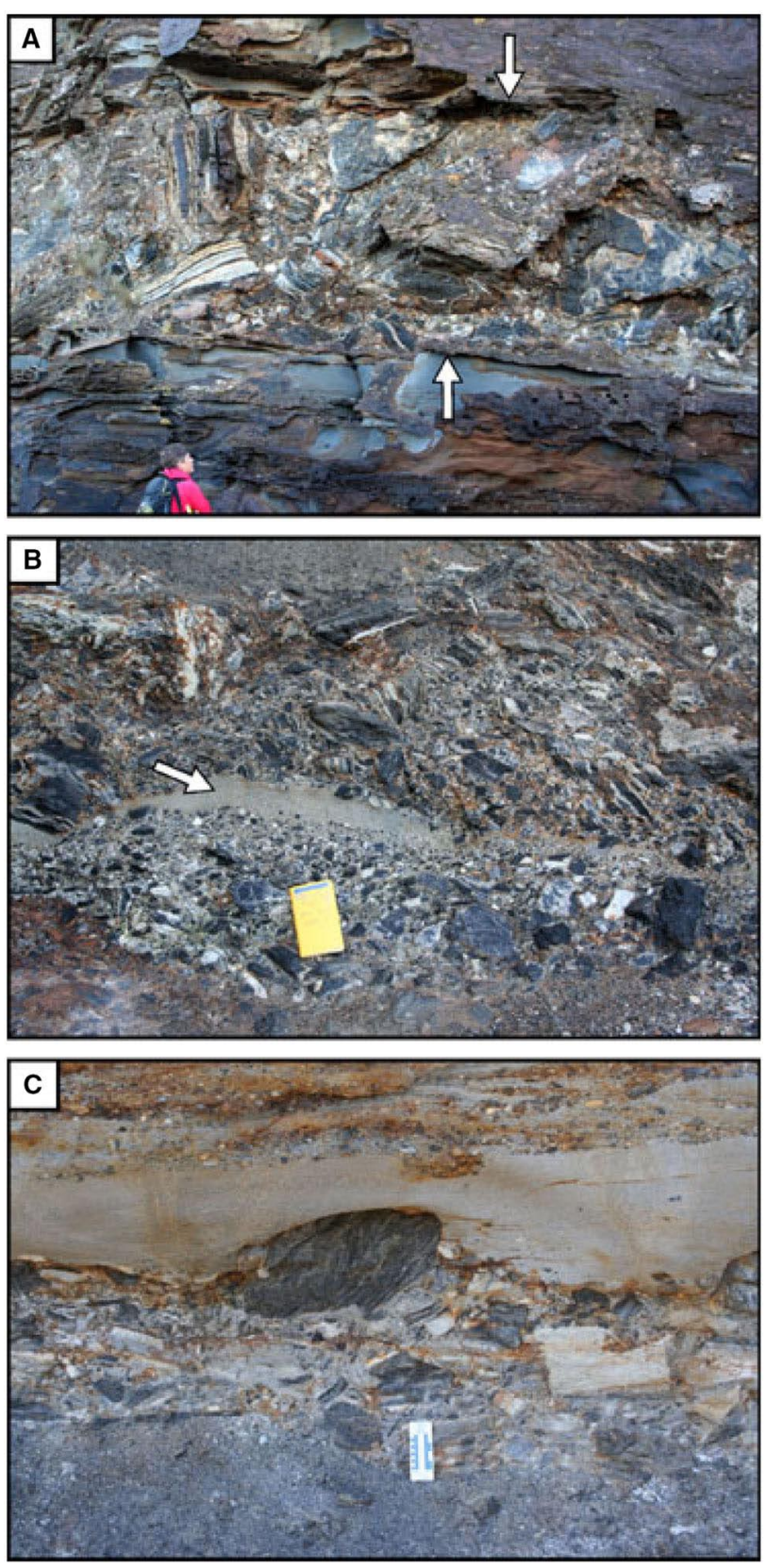

Figure 6. Marine sediment gravity flow facies association. (A) View of breccia and gravelly upper shoreface deposits; note the sharp contacts between these units (arrows). Interval is between 10 and $20 \mathrm{~m}$ in the Myrtle Beach measured section, person for scale $\sim 1.7 \mathrm{~m}$ tall. (B) Gradational contact between breccia and sandstone lens (arrow). Photograph from $\sim 14 \mathrm{~m}$ in the Myrtle Beach section, field book is $19 \mathrm{~cm}$ tall. (C) Contact between breccia and overlying gravelly upper shoreface deposits showing encasement of a protruding clasts by overlying lithologies. Photograph from $\sim 18 \mathrm{~m}$ in the Myrtle Beach section, $1 \mathrm{~cm}$ gradations on left-hand side of photoscale.

association with the upper shoreface deposits indicate that this facies association was deposited in a shallow marine environment in upper shoreface water depths (Figure 7). Paleoflow data, correlation be- tween outcrops, and marked thickness changes in breccias and sandstone interbeds indicate that the sediments flowed down an east-dipping slope and thickened basinwards (Gostin, 1968). The cross-sectional geometry and association with breccias suggest that the lobe of the conglomerate in the Dark Beach North section was emplaced by debris flow processes. Because other conglomerate occurrences within this facies association occur at the top of breccias, they are interpreted as recording wave reworking. The thin sandstones that locally split coarse-grained units are interpreted as shallow marine (shoreface?) sandstones deposited during quiescent periods between debris flows. Debris flow facies were not bioturbated, indicating rapid emplacement and/or conditions hostile to marine invertebrates.

\section{Upper shoreface facies association}

\section{Description}

The upper shoreface facies association is found throughout the Dark Beach North and Myrtle Beach sections, and in the basal $\sim 24 \mathrm{~m}$ of the Emily Miller Beach section (Table 1; Figures 4 and 7). Constituent lithofacies include variably bioturbated, pebbly sandstone with trough cross-beds and abundant conglomeratic horizons with clasts up to $0.30 \mathrm{~m}$ in diameter. This facies association ranges from 1.1 to $17.0 \mathrm{~m}$ in thickness, has sharp contacts with the marine sediment gravity flow facies association and a gradational contact with overlying gravelly middle shoreface deposits in the Emily Miller Beach section.

Fine-grained to very coarse-grained lithic sandstone is the most abundant lithology in the clast-rich shoreface facies association. Sandstones typically occur in thick, amalgamated packages wherein discrete beds are separated by erosional contacts (Figure 7A). Isolated conglomeratic intervals are abundant within sandstones and bounded by gradational to erosional contacts. Sedimentary structures include trough, hummocky and swaley cross-strata as well as low-angle to planar laminae. As indicated on the measured section, some intervals contain both hummocky cross-strata (sensu stricto, Harms et al., 1975) and local swaley cross-stratified intervals with abundant lowangle laminae and infilled swales. Trough cross-beds near the base of the Myrtle Beach section record paleoflow to the west $\left(\right.$ mean $=282^{\circ}, n=16$ ).

Clasts within this facies association range from granules to large pebbles $(<0.32 \mathrm{~m}$ diameter) and are typically incorporated into low-angle, trough, hum- 

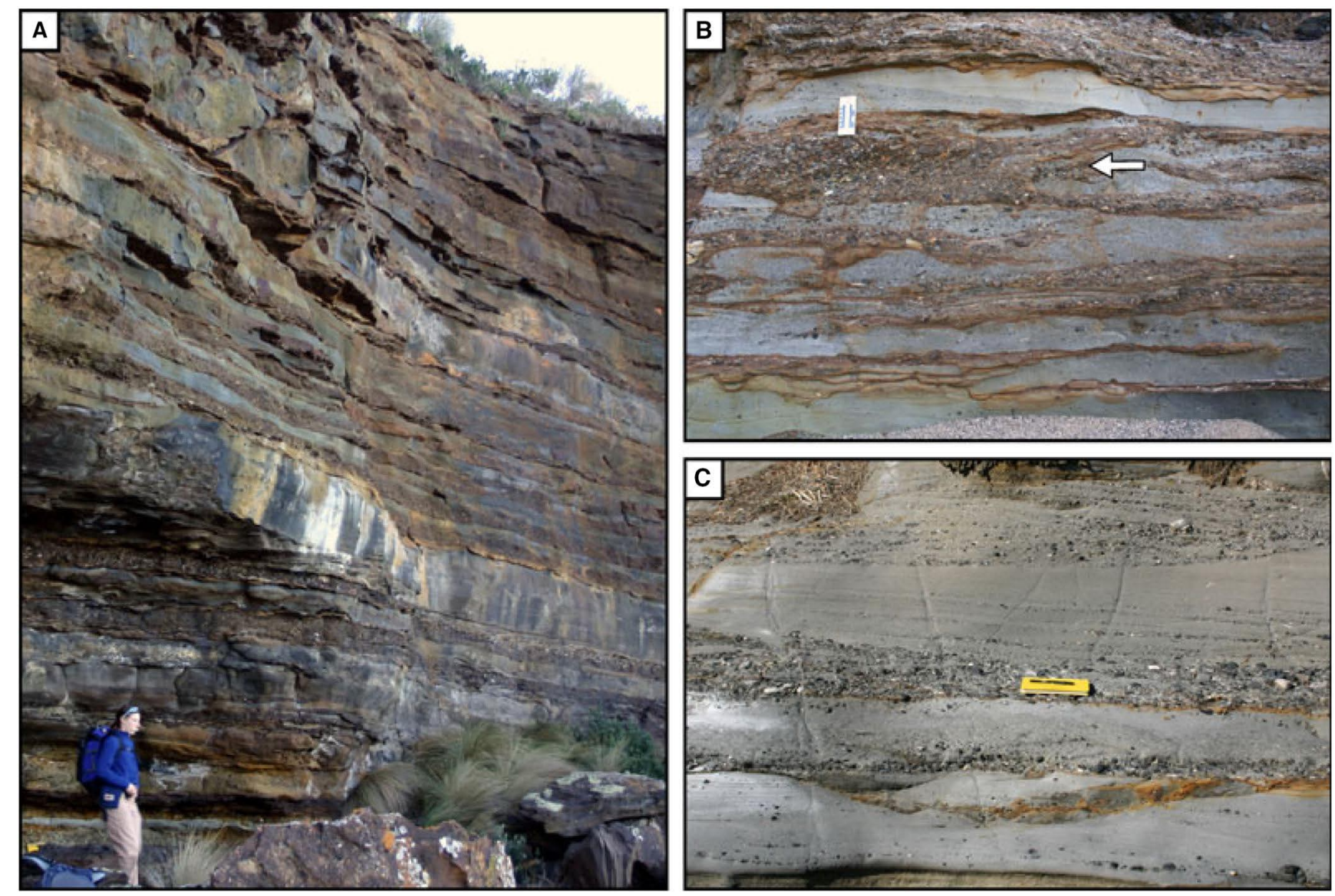

Figure 7. Upper shoreface facies association. (A) Thick interval of gravelly upper shoreface deposit between $\sim 13$ and $34 \mathrm{~m}$ in the Myrtle Beach section; person for scale $\sim 1.7 \mathrm{~m}$ tall. (B) Reworked ice-rafted debris in trough cross-bedded upper shoreface deposits (left of arrow). Photograph from $\sim 6 \mathrm{~m}$ in the Dark Beach North section, $1 \mathrm{~cm}$ gradations on left-hand side of photoscale. (C) Reworked ice-rafted debris in low-angle laminated and hummocky cross-stratified upper shoreface deposits. Photograph from $\sim 11 \mathrm{~m}$ in Myrtle Beach section, long axis of field book is $19 \mathrm{~cm}$.

mocky and swaley cross-stratified sandstone (Figure $7 \mathrm{~B}$ and $\mathrm{C}$ ). Conglomeratic intervals within sandstones contain $10 \%$ to $70 \%$ clasts, range between 0.1 and $1.0 \mathrm{~m}$ in thickness, and represent between $10 \%$ and $50 \%$ of the facies association. Conglomeratic horizons lack internal stratification and some contain bivalve shell fragments (Eurydesma?) and large woody debris. The concentration of coarse-grained detritus within this association is second only to the marine sediment gravity flow facies association.

Gravelly upper shoreface deposits are typically weakly bioturbated (B.I. $=0$ to 2 ) and contain a lowdiversity trace fossil suite composed of Diplocraterion habichi and Arenicolites.

\section{Interpretation}

Trough cross-beds, a hallmark of this facies association (Clifton et al., 1971; Hunter et al., 1979; Howard \& Reineck, 1981), record the former presence of landward-migrating three-dimensional dunes that formed during fair-weather conditions in upper shoreface water depths (Greenwood \& Mittler, 1985). The presence of low-angle, hummocky and swaley cross-stratification indicates heightened storm influence in this energetic, upper shoreface environment (Figure 5).

The presence of ice-rafted debris in overlying horizons (see below) supports the long-standing interpretation of conglomeratic horizons as having been originally derived from ice-rafted debris (Thiele, 1903; Gostin, 1968; Gostin \& Herbert, 1973; Eyles et al., 1998), although reworking of debris flow deposits cannot be entirely ruled out. Assuming a significant glacial contribution, the sheer abundance and regional provenance of gravel-sized clasts in the Wasp Head Formation suggests delivery from nearby tidewater glaciers and/or seasonal sea or river ice (Gostin, 1968; Gostin \& Herbert, 1973). Pervasive reworking of gravelsized clasts probably records ongoing disturbance of the sediment surface via fair-weather waves. Shallow water depths of the upper shoreface may have limited 

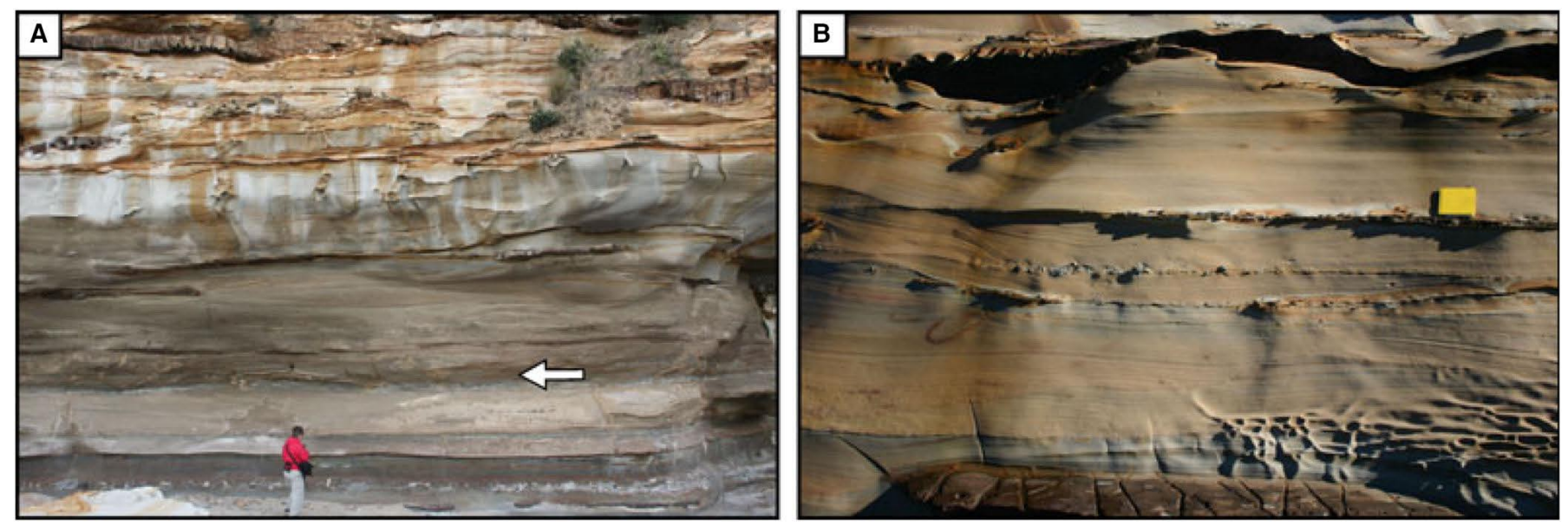

Figure 8. Middle shoreface facies association. (A) View of middle shoreface deposits between $\sim 42$ and $51 \mathrm{~m}$ in the Emily Miller Beach section. Arrow is placed at the top of a relatively fine-grained bed marking the top of the underlying delta-influenced deposits. Person for scale $\sim 1.8 \mathrm{~m}$ tall. (B) Detail of sandy middle shoreface deposits. Photograph from $\sim 50 \mathrm{~m}$ in the Emily Miller Beach section, field book is $17 \mathrm{~cm}$ wide.

the maximum size of floating sea ice in this environment, thus preventing the introduction of the cobblesized and boulder-sized clasts that are ubiquitous in the other facies associations. The facies association is remarkably similar to modern sediments in the North Pacific and Far Eastern Seas (Lisitzin, 2002) and Neogene deposits in the north-western USA (Leithold \& Bourgeois, 1984; Campbell et al., 2006).

Gravelly upper shoreface deposits contain an impoverished expression of the Skolithos Ichnofacies, indicative of high-energy shoreface environments with persistently loose, shifting substrates. Large woody debris indicates a terrestrial climate that was suitable for plant growth for at least part of the year.

\section{Middle shoreface facies association}

\section{Description}

The middle shoreface facies association occurs at 17 to $38 \mathrm{~m}$ and 43 to $51 \mathrm{~m}$ in the Emily Miller Beach section (Table 1; Figures 4 and 8). These deposits consist of weakly bioturbated, fine-grained to coarse-grained sandstone with conglomeratic beds containing clasts up to $\sim 2 \mathrm{~m}$ in diameter. Middle shoreface deposits have sharp to gradational contacts with overlying and underlying facies associations.

Fine-grained to coarse-grained sandstone is the most abundant lithofacies in the middle shoreface facies association. Sandstones become increasingly quartzose, well-sorted and finer-grained upwards throughout the formation, a trend particularly noticeable in this facies association (Gostin \& Herbert,
1973). Individual beds of sandstone are defined by low-angle erosion surfaces. Sedimentary structures include horizontal to low-angle laminae and ubiquitous swaley and hummocky cross-strata. Unlike upper shoreface deposits, trough cross-beds are absent. Locally, gravel-sized clasts may reach abundances of $20 \%$ and occur as discrete conglomeratic beds/ lenses, isolated clasts, or may be reworked into discrete swales and hummocky cross-stratified intervals. Individual clasts range from granules to boulders up to $2.0 \mathrm{~m}$ in diameter.

Weak bioturbation (B.I. $=0$ to 1 ) is characteristic; ichnogenera include D. parallelum, Rosselia stalks, Rosselia rotatus, Planolites, and Paleophycus tubularis, fugichnia, and rare Macaronichnus and Diplocraterion habichi. Some conglomeratic horizons contain woody plant debris and brachiopod and bivalve shell fragments.

\section{Interpretation}

Ubiquitous hummocky and swaley cross-strata indicate that this facies association was deposited in energetic, middle shoreface water depths (Figure 5). The incorporation of clasts into hummocks and swales records remobilization of the sediment surface during storm conditions. Dispersed individual clasts within sandstones may represent either individual clasts dropped from floating ice or clasts remobilized during storms.

The presence of the Skolithos Ichnofacies with robust and resilient detritus feeders is consistent with a middle shoreface interpretation. The scarcity of trace fossils suggests high depositional rates, an in- 

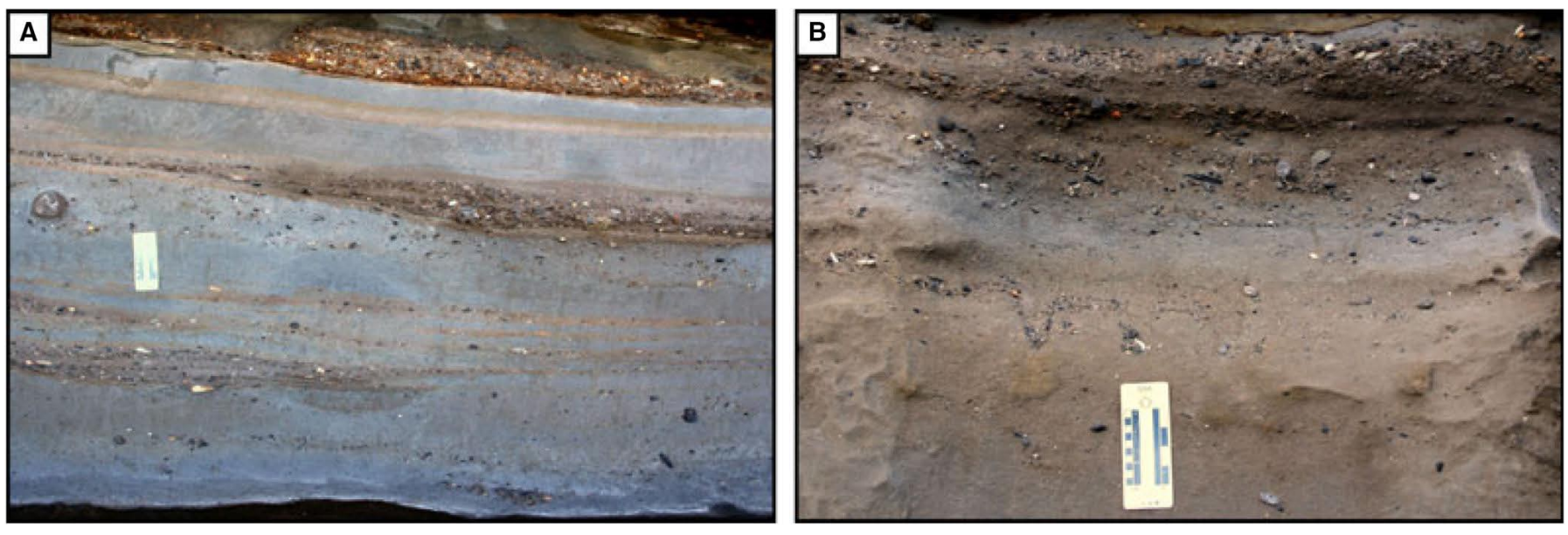

Figure 9. Lower shoreface facies association. (A) Ice-rafted debris in low angle and swaley cross-stratified, lower shoreface deposits. Photograph from $\sim 14 \mathrm{~m}$ in the Emily Miller Beach section, $1 \mathrm{~cm}$ gradations on left-hand side of photoscale. (B) Heavily bioturbated interval within lower shoreface deposits, note the multiple Conichnus just above the photoscale and the redistribution of ice-rafted debris by bioturbation. Photograph from $\sim 12 \mathrm{~m}$ in the Emily Miller Beach section, $1 \mathrm{~cm}$ gradations on left-hand side of photoscale.

crease in storm activity, cryptic deltaic influence, exceptionally cold conditions or some other factor that made conditions unfavorable for invertebrate activity. Broadly similar deposits have been described from the North Pacific and Far Eastern Seas (Lisitzin, 2002), Quaternary deposits on Baffin Island (Mode et al., 1983), Quaternary-modern sediments from the Gulf of Alaska (Molina \& Carlson, 1980; Molina, 1983), and the Neogene Yakataga (Eyles et al., 1991) and Quinault Formations (Campbell et al., 2006).

\section{Lower shoreface facies association}

\section{Description}

The lower shoreface facies association (Table 1; Figures 4 and 9) occurs at 61 to $74 \mathrm{~m}$ in the Emily Miller Beach section, and possibly at 11 to $17 \mathrm{~m}$ in the Emily Miller Beach section and 18 to $22 \mathrm{~m}$ in the Myrtle Beach section (latter two diagnoses equivocal). These deposits consist of intervals of muddy, highly bioturbated sandstone with relict sedimentary structures locally. Lower shoreface deposits have sharp to gradational contacts with overlying and underlying facies associations.

Muddy, fine-grained to conglomeratic sandstone is the most abundant lithofacies in the lower shoreface deposits. Although sedimentary structures are typically destroyed by bioturbation, horizontal to lowangle laminae, swaley cross-strata and hummocky cross-strata are preserved locally. Clasts up to $\sim 50 \mathrm{~cm}$ in diameter occur either as isolated clasts within intensely bioturbated sandstones or as discrete lenses or beds; some intervals contain as much as $20 \%$ gravelsized clasts.
Lower shoreface deposits contain markedly more intense (B.I. $=1$ to 5 ) and diverse bioturbation than upper and middle shoreface deposits (Figure 9). Common ichnogenera include Rosselia rotatus, Phycosiphon, Planolites, Diplocraterion habichi, D. parallelum, Siphonichnus, bivalve equilibrium adjustment structures, Rhizocorallium, Cosmorhaphe, Paleophycus tubularis, P. heberti, Chondrites, Thalassinoides, Asterosoma, Taenidium isp., fugichnia and Macaronichnus simplicatus. Many conglomeratic horizons contain woody plant debris and abundant, relatively unabraded, accumulations of brachiopod and bivalve shell fragments; Eurydesma shells are particularly abundant at $\sim 72 \mathrm{~m}$ in the Emily Miller Beach section.

\section{Interpretation}

The combination of intense and diverse bioturbation, and relict laminated and hummocky cross-stratified intervals, indicates that this facies association was deposited largely during storm conditions and was subsequently bioturbated during fair-weather periods (Figure 5). The presence of isolated outsized clasts within heavily bioturbated intervals may record homogenization of clast-rich ice-rafted debris layers by bioturbation and/or sporadic dumping of individual clasts. Within this facies association, more proximal deposits are probably represented by distal expressions of the Skolithos Ichnofacies whereas more distal deposits are represented by a very diverse, proximal expression of the Cruziana Ichnofacies. This depositional environment is interpreted as being broadly similar to the modern, high-latitude examples listed for the middle shoreface deposits. 
Delta-influenced, lower shoreface-offshore transition facies association

\section{Description}

Delta-influenced lower shoreface-offshore transition deposits occur near the top of the Wasp Head Formation at the Durras North and Depot Beach sections, and between 38 to $43 \mathrm{~m}$ and 60 to $61 \mathrm{~m}$ at the Emily Miller Beach section (Figure 4). Drapes of carbonaceous claystone are diagnostic and found interbedded with fine to medium-grained sandstone, thin conglomerates with clasts up to $2 \mathrm{~m}$ in diameter, admixed sandstone and mudstone, and silty to clayey mudstone (Table 1; Figures 4 \& 10). Near the top of the formation these lithologies are complexly interbedded and laterally variable. Discrete intervals of this facies association range from 0.9 to $7.3 \mathrm{~m}$ in thickness and have sharp to sharply gradational $(<1 \mathrm{~m})$ contacts with overlying and underlying facies associations.

At Durras North and Depot Beach, drapes of carbonaceous claystone occur as very thin laminae $(<1 \mathrm{~mm})$ within weakly bioturbated, fine-grained sandstones $(<0.7 \mathrm{~m}$ thick; Figure $10 \mathrm{~A} \& \mathrm{~B})$. These micro-laminated sandstones contain $<10 \%$ muddy laminae and define low-angle laminae, wave ripples, and small-scale hummocky cross-strata on adjacent sandstone bed contacts. Bioturbation ranges from absent to uncommon (B.I. $=0$ to 2 ) and Teichichnus was the only observed ichnogenus. Delta-influenced beds near the top of the formation pinch out laterally and have sharp to sharply gradational contacts with other units. Carbonaceous claystone also occurs as thin, discontinuous interlaminae and interbeds $(1 \mathrm{~mm}$ to $3 \mathrm{~cm}$ ) that make up as much as $50 \%$ of wavy-laminated fine-grained sandstones (Figure 10C). Bioturbation is more intense in interbedded intervals (B.I. $=4$ to 6) and sedimentary structures are rarely preserved. Trace fossil diversity is limited; observed ichnogenera include Planolites, Thalassinoides, small Teichichnus, Phycosiphon, and Asterosoma. At Depot Beach a $12 \mathrm{~cm}$ thick, laminated black claystone blankets and preserves the three-dimensional form of symmetrical ripples in the underlying sandstone (Figure 10B).

Associated sandstones near the top of the formation are $<1.00 \mathrm{~m}$ thick, fine-grained to medium-grained, and organized into weakly bioturbated "clean" intervals with interbeds of intensely bioturbated silty sandstone. Weakly bioturbated beds (B.I. $=0$ to 1 ) are organized into wave ripples, hummocky cross-strata and low-angle lamination/cross-bedding, and have rare Rosselia, Teichichnus, Diplocraterion habichi, and Paleophycus. Silty interbeds are intensely bioturbated (B.I. $=4$ to 6), and have a diverse trace fossil assemblage that includes abundant Rosselia, D. habichi, Teichichnus, Rhizocorallium, Zoophycos, Phycosiphon, Planolites, Paleophycus, Asterosoma, and Chondrites. Contacts between the two types of sandstones are generally sharp. Laterally discontinuous $(<10 \mathrm{~m})$ lenses of conglomerate (granules to boulders) are common within all sandstones.

The two occurrences of delta-influenced deposits within the Emily Miller Beach section contain wavy, discontinuous interbeds of carbonaceous claystone within shoreface sandstones and intensely bioturbated (B.I. $=5$ to 6 ), admixed sandstone and mudstone (Figure 10D). Relict hummocky and swaley cross-stratification are present locally. These intervals have an extremely diverse trace fossil assemblage similar to that of the silty interbeds described above. These beds occur within packages of clean, fine-grained sandstone and laterally extensive conglomerate beds ( $<50 \mathrm{~cm}$ thick) with clasts up to $2 \mathrm{~m}$ in diameter (Figure 10E and F).

\section{Interpretation}

Delta-influenced deposits near the top of the Wasp Head Formation contain hummocky cross-strata, wave ripples, impoverished distal expressions of the Skolithos Ichnofacies and stressed, proximal expressions of the Cruziana Ichnofacies. Together, these characteristics suggest deposition in lower shoreface to offshore transition water depths. However, this facies association differs from other units deposited in similar water depths in that it contains sedimentological and ichnological evidence to suggest that deposition occurred within proximity to contemporaneous deltaic outflows. Sparsely to unbioturbated carbonaceous claystone drapes may reflect flocculation and settling of hypopycnal buoyant mud plumes produced via heightened river discharge associated with storms (MacEachern et al., 2005). The mudstone drapes are rich in phytodetrital material and locally contain synaeresis cracks which may reflect deposition in association with freshets and associated hyperpycnal fluid mud flows, delivered during heightened post-storm river outflow (MacEachern et al., 2005). Additionally, marked changes in trace fossil assemblage diversities, and sporadic distribution of bioturbation throughout this facies association, suggest fluctuating environmental conditions such as salinity, sedimentation rates, substrate consistency, ox- 

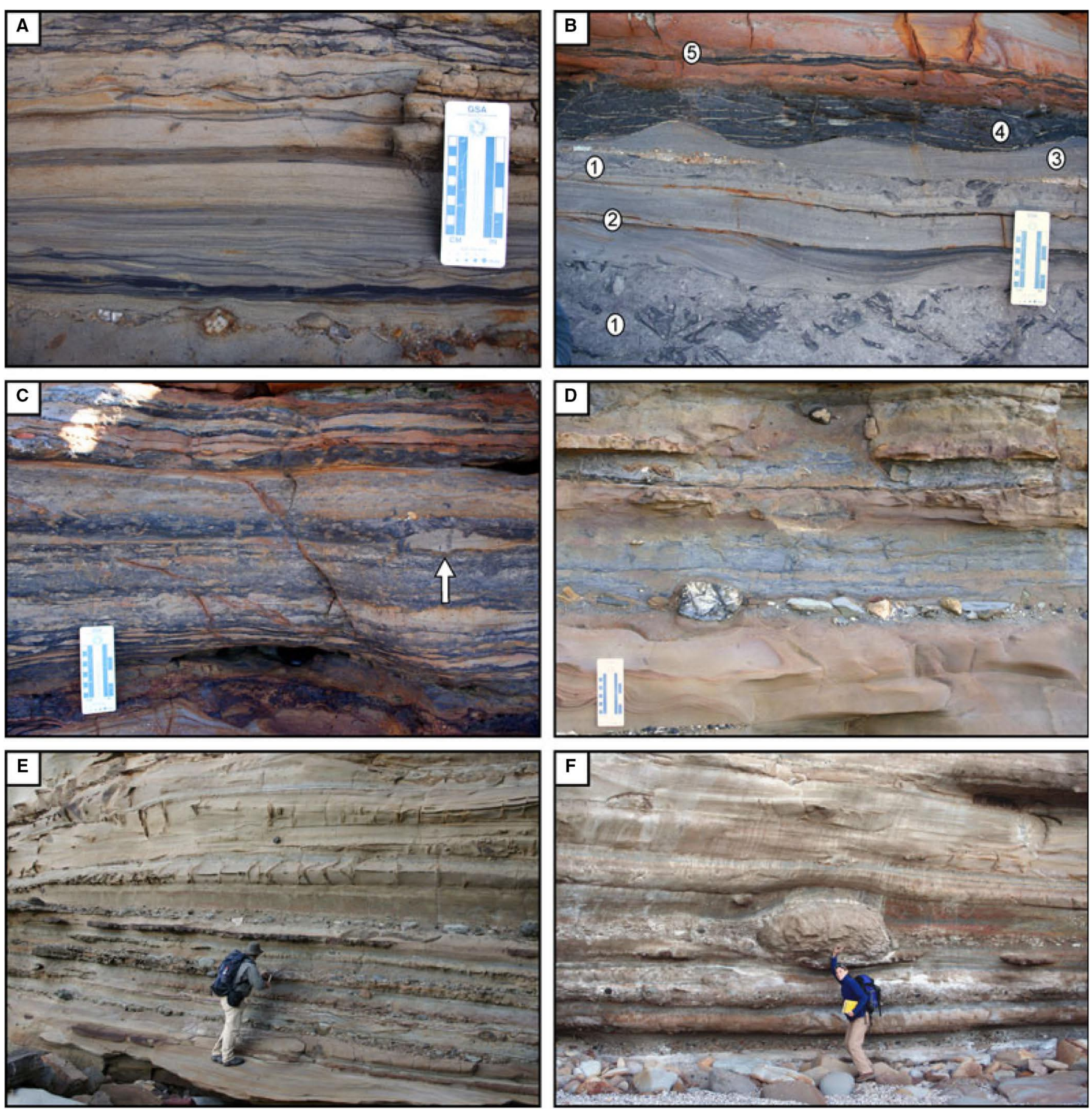

Figure 10. Delta-influenced, lower shoreface-offshore transition facies association. (A) Very thin laminae of carbonaceous mudstone within a lower shoreface sandstone. Photograph from $\sim 1 \mathrm{~m}$ in the Depot Beach section, $1 \mathrm{~cm}$ gradations on left-hand side of photoscale. (B) Variable and complexly interbedded lithologies of the delta-influenced facies association at $\sim 1.5 \mathrm{~m}$ in the Depot Beach section. Lithologies include: (1) intensely bioturbated sandstone; (2) swaley cross-stratified sandstone with carbonaceous laminae; (3) sandstone with well-preserved symmetrical ripples; (4) carbonaceous mudstone draping symmetrical ripples in sandstone; and (5) interbedded sandstone and carbonaceous mudstone similar to that in Figure 9C; $1 \mathrm{~cm}$ gradations on left-hand side of photoscale. (C) Thin, discontinuous interlaminae and interbeds of carbonaceous mudstone within wavy-laminated finegrained sandstone. Note abundant bioturbation and small hummocky cross-strata (above arrow). Photograph from $\sim 1.5 \mathrm{~m}$ in the Depot Beach section, $1 \mathrm{~cm}$ gradations on left-hand side of photoscale. (D) Detail of interval shown in (A), note the abundant carbonaceous laminae, admixed sandstone/mudstone, and pervasive bioturbation; $1 \mathrm{~cm}$ gradations on left-hand side of photoscale. (E) Delta-influenced, lower shoreface-offshore transition deposits between 38 and $42 \mathrm{~m}$ in the Emily Miller Beach section. Note the laterally extensive ice-rafted debris horizons and the drab, admixed sandstone/mudstone intervals with carbonaceous laminae (seen in more detail in Figure 9D). Person for scale $\sim 1.8 \mathrm{~m}$ tall. (F) Large, ice-rafted clast within delta-influenced interval at 38 to $42 \mathrm{~m}$ in the Emily Miller Beach section. Person for scale $\sim 1.7 \mathrm{~m}$ tall. 
ygen levels, food and light availability, heightened turbidity, etc. Intervals with a distal expression of the Skolithos Ichnofacies record proximal lower shoreface conditions, whereas stressed and proximal expressions of the Cruziana Ichnofacies indicate deposition in distal lower shoreface or offshore transition settings. These characteristics are consistent with deposition in a storm-dominated to wave-dominated delta front (Bann \& Fielding, 2004), with additional environmental stresses potentially enhanced by the contribution of glacial meltwater (Phillips et al., 1991). Similar deltaic deposits have been described from the Cretaceous of western Canada and from elsewhere in the Permian of eastern Australia (Saunders et al., 1994; Gingras et al., 1998; Bann \& Fielding, 2004; Bann et al., 2004).

The delta-influenced facies association at 38 to $43 \mathrm{~m}$ in the Emily Miller Beach Formation also contains wavy carbonaceous laminae, but these clayrich beds are discontinuous and represent a smaller proportion of the facies association than those described above. Although the presence of hummocky cross-stratified sandstone and admixed sandstone and mudstone suggests deposition in lower shoreface to offshore transition water depths, the presence of sparsely burrowed carbonaceous mudstone drapes, sporadic bioturbation distributions and stressed trace fossil assemblages is suggestive of a deltaic influence. These characteristics are consistent with deposition in a wave-dominated distal delta front or on the updrift side of the delta where the environmental stresses were less severe (Bann \& Fielding, 2004; MacEachern et al., 2005). Greater water depths allowed for the introduction of large ice-rafted clasts (up to $2 \mathrm{~m}$ ) via larger blocks of floating ice and for the accumulation of extensive, relatively intact clast-rich horizons without major reworking by storm events.

\section{Offshore transition-offshore facies association}

\section{Description}

The offshore transition-offshore facies association occurs at $\sim 51$ to $60 \mathrm{~m}$ and $\sim 73$ to $79 \mathrm{~m}$ in the Emily Miller Beach section, and in the lower $\sim 5 \mathrm{~m}$ of the Durras North section (Table 1; Figures 4 and 11). Lithofacies include mudstones, admixed sandstone and mudstone, and muddy sandstones, all of which contain conglomeratic layers and outsized clasts; most lithologies are pervasively bioturbated. This facies association occurs as tabular intervals that range from $4.6 \mathrm{~m}$ (incompletely exposed) to $8.9 \mathrm{~m}$ thick, and shows sharp basal contacts and gradational $(\leq 1 \mathrm{~m})$ top contacts.

Silty mudstones and admixed sandstone and mudstone are the most abundant lithofacies in offshore transition-offshore deposits (Figure 10A and B). Relict muddy horizons are present within admixed intervals, indicating that homogenization was the result of biogenic mixing (B.I. $=4$ to 6). Ichnotaxa in the muddy and admixed intervals include Phycosiphon, Cosmorhaphe, Planolites, Chondrites, Paleophycus heberti, Rhizocorallium, Thalassinoides, Zoophycos, Asterosoma, small Rosselia, and rare Diplocraterion habichi. Clast-rich horizons (granules to boulders) are present locally and outsized clasts are ubiquitous (5\% to $15 \%$ of unit volume). The admixed zone at the base of the Durras North section contains numerous swales filled with low-angle laminated, fine-grained sandstone (Figure 10D). Swales, and the thin sandstone beds to which they connect, become thicker, more laterally extensive and better stratified (B.I. = 1 to 3 ) upwards through this zone.

Scattered beds of fine to medium-grained, muddy sandstone up to a meter thick are present locally within this facies association, especially between 51 and $60 \mathrm{~m}$ in the Emily Miller Beach section. Where visible, bedding is defined by hummocky cross-strata with a formative bedform wavelength of $\sim 10 \mathrm{~m}$. Sandstones also contain conglomeratic lenses with bivalve shells, dispersed outsized clasts and laminae lined with granules to pebbles. The bioturbation index within sandy intervals is generally sparse to low (B.I. $=1$ to 2), with locally intense bioturbation (B.I. =5). Trace fossils in the muddy sandstones include Diplocraterion habichi, Phycosiphon, Taenidium isp., Psammichnites, Asterosoma, Cosmorhaphe, Paleophycus tubularis, fugichnia and Diplocraterion parallelum.

\section{Interpretation}

The offshore transition-offshore facies association was deposited in water depths that were below fairweather wave base and locally below storm wave base. Admixed intervals probably represent interbeds of sand, mud and clast-rich layers that were completely homogenized by biogenic activity. Outsized clasts are interpreted as ice-rafted debris. The relative abundance of muddy sediment, pervasive bioturbation and the presence of an archetypal Cruziana Ichnofacies suggest that these units were generally deposited below fair-weather wave base in a fully marine setting. Sandy to silty mudstones containing 

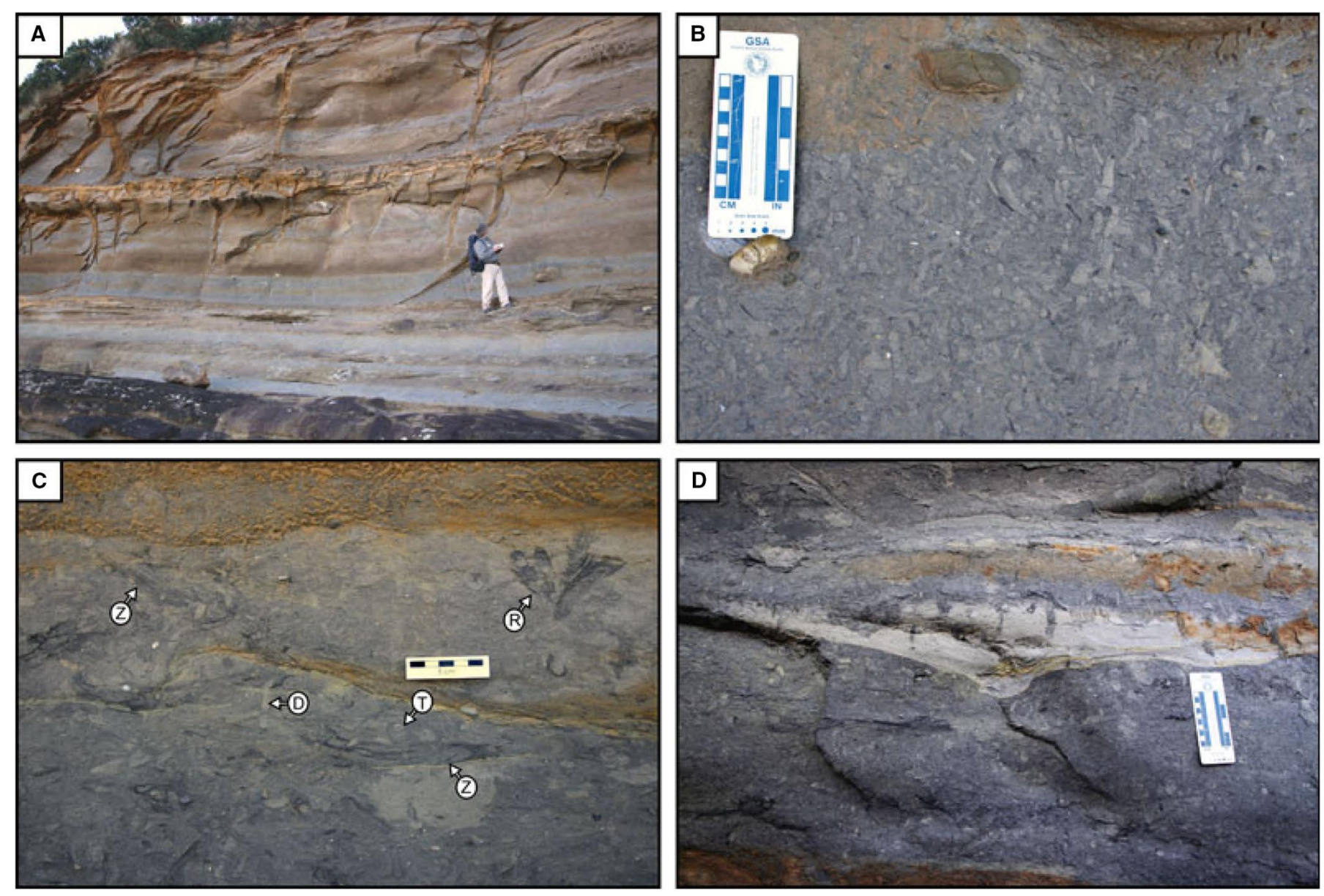

Figure 11. Offshore transition-offshore facies association. (A) View of interbedded lower shoreface and offshore transition-offshore deposits between $\sim 55$ and $60 \mathrm{~m}$ in the Emily Miller Beach section. Lower shoreface sandstones are the prominent resistant beds, and the muddy, intensely bioturbated deposits of the offshore transition-offshore deposits intervals weather recessively. Person for scale $\sim 1.8 \mathrm{~m}$ tall. (B) Detail of the offshore transition-offshore deposits shown in (A). Note the redistribution of ice-rafted debris via pervasive bioturbation; $1 \mathrm{~cm}$ gradations on left-hand side of photoscale. (C) Diverse trace fossil assemblages within the offshore transition deposits commonly include Zoophycos (Z), Rosselia (R), Teichichnus (T), and Diplocraterion habichi (D). Photograph from $\sim 3.5 \mathrm{~m}$ in the Durras North measured section; $1 \mathrm{~cm}$ gradations on photoscale. (D) Isolated sandstone swale within admixed sandstone/mudstone interval at $\sim 3 \mathrm{~m}$ in the Durras North section; $1 \mathrm{~cm}$ gradations on left-hand side of photoscale.

a distal expression of the Cruziana Ichnofacies probably record lower offshore water depths whereas those with an archetypal expression of the Cruziana Ichnofacies were probably deposited in an upper offshore setting. Muddy sandstones, which generally exhibit a diverse expression of the Cruziana Ichnofacies, represent deposition in an offshore transition setting.

The complexly interbedded interval between 51 and $60 \mathrm{~m}$ in the Emily Miller Beach section records numerous alternations between lower offshore, upper offshore and offshore transition deposits. The presence of offshore transition deposits (muddy sandstone) records a phase of deposition near fair-weather wave base-conditions generally shallower than for other occurrences of this facies association.

\section{Overview of Depositional Environments}

The Wasp Head Formation represents a variety of shoreface to offshore marine environments (Figure 5). Conglomeratic horizons and outsized clasts are present (to varying degrees) in all facies associations indicating that dropping and dumping of ice-rafted sediment was an important and ongoing process during deposition of this unit. Cold water temperatures are also supported by the presence of ice-rafted debris and Eurydesma (Gostin \& Herbert, 1973; Runnegar, 1979), as well as glendonites and iceberg keel turbates higher in the succession (Carr et al., 1989; Eyles et al., 1997; Thomas et al., 2004). 
Shoreface deposits make up the majority of the Wasp Head Formation. Trace fossils and sedimentary structures contained within these facies associations are consistent with deposition in upper to lower shoreface environments on a variably storminfluenced coastline. The paucity of large clasts $(>30 \mathrm{~cm})$ in the upper shoreface deposits suggests fair-weather reworking in water depths that were shallow enough to prevent large, sediment-laden blocks of ice from being transported into the breaker zone (Molina, 1983). In contrast, the larger clasts (up to $2 \mathrm{~m}$ ) and more extensive conglomerate horizons found in middle and lower shoreface deposits suggest accumulation of ice-rafted debris in deeper waters. At the formation scale, the amount of ice-rafted debris decreases upwards, a relationship that suggests decreasing glacial influence. Although evidence remains equivocal, the marked increase in trace fossil diversity and abundance near the top of the formation probably record some combination of increased water depths, decreased sedimentation rates and/or a climate that became increasingly favorable for invertebrate colonization.

The remaining facies associations record departures from the "normal" shoreface conditions that typify the Wasp Head Formation. The marine sediment gravity flow facies association was deposited as debris flows derived from the western basin margin episodically spilled into the upper shoreface. Carbonaceous claystone interbeds and marked changes in trace fossil abundance and diversity in delta-influenced deposits attest to marked changes in salinity, turbidity and/or sedimentation rates (Bann \& Fielding, 2004; Bann et al., 2004; MacEachern et al., 2005) in a range of shoreface to offshore-transition water depths. Although there may be deltaic imprints throughout the rest of the Wasp Head Formation, it is impossible to diagnose all facies as specifically deltaic at the present time.

Overall, the depositional environment of the Wasp Head Formation shares many characteristics with modern, high-latitude coastal systems of the northern hemisphere. A comparable facies assemblage is present in the Gulf of Alaska, where outlet glaciers historically delivered sediment-laden icebergs into a shallow marine environment that includes gravelly to muddy substrates (Molina \& Carlson, 1980; Molina, 1983). Much like the Gulf of Alaska, the Wasp Head Formation represents an environment where forests thrived in close proximity to glaciers and sea ice. Similar facies have also been described from high-latitude coastlines in Alaska and Canada (Forbes \& Syvitski, 1994; Hill et al., 1994), as well as the Bering Sea, Sea of Okhotsk and northern Pacific Ocean (Lisitzin, 2002).

\section{Stratigraphic Architecture}

The basal part of the Wasp Head Formation largely consists of $\sim 24 \mathrm{~m}$ of interbedded marine sediment gravity flows and upper shoreface deposits that pass upwards into $\sim 26 \mathrm{~m}$ of middle shoreface deposits in the Emily Miller Beach section (Figure 12). It is difficult to correlate the shoreface successions in the upper part of the Myrtle Beach and Dark Beach North sections, and the facies variability seen in these successions may represent bathymetric differences associated with early basin topography and thickness of debris flow deposits. Overall, the basal $\sim 50 \mathrm{~m}$ of the Wasp Head Formation represents a gradual deepening-upwards succession with no well-developed internal cyclicity. The overlying $\sim 45 \mathrm{~m}$ of section consists of middle to lower shoreface, delta-influenced lower shoreface-offshore, and offshore transition-offshore deposits organized into three shallowing upward cycles (parasequences). The Wasp Head Formation is separated from the dark, laminated, offshore deposits of the lower Pebbley Beach Formation by a pronounced flooding surface with a local conglomeratic lag formed by winnowing or accumulation of ice-rafted debris during a period of minimal sedimentation.

Given the growing body of evidence for a late Asselian to early Sakmarian glacial event in eastern Australia (Montañez et al., 2007; Fielding et al., 2008) and the sedimentological evidence of glacial influence within this unit, interpretation of the stratigraphic architecture of the Wasp Head Formation must take into account potential glacial drivers. Possible glacial striae on the basal unconformity (Gostin, 1968) suggest that Wasp Head Formation sediments were deposited shortly after the retreat of glacial ice. The gradual deepening upward trend observed in the lower part of the formation may, therefore, record a transition from glacioisostatic rebound to the regional extension that characterized the southern part of the Sydney Basin at this time (Fielding et al., 2001).

As sedimentation continued within this tectonically active basin, glacioeustatic fluctuations or autogenic progradational cycles may have been responsible for the stacked parasequences in the upper part of the formation. The shift to the parasequence-dom- 


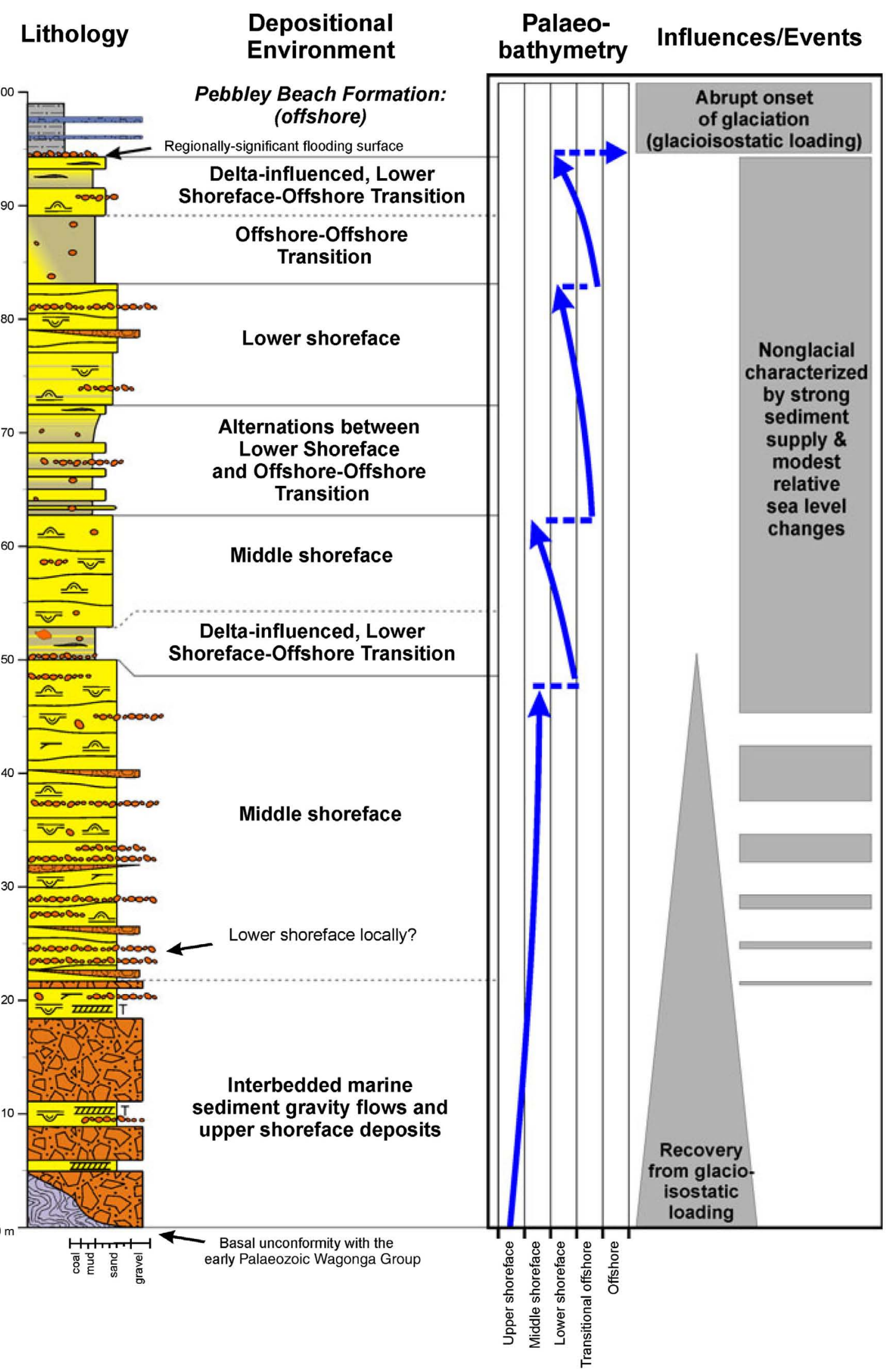

Figure 12. Summary section of the Wasp Head Formation showing lithologies, depositional environments, paleobathymetric trends, and important events and influences during the deposition of this unit. 
inated architecture of the upper Wasp Head Formation is loosely accompanied by a progressive decrease in the amount and size of ice-rafted debris. These patterns are consistent with a transition to broadly nonglacial conditions (in the southern Sydney Basin) wherein there was a progressive amelioration of climate, the basin experienced a gradual decrease in glacioisostatic rebound, and sea-level changed in response to waxing and waning of glacial ice elsewhere in Gondwana.

A crude approximation of the magnitude of paleobathymetric fluctuations can be made by comparison with continental shelves in similar latitudes and tectonic settings (non-convergent margins). Fairweather wave base is estimated to have occurred at $\sim 30 \mathrm{~m}$ depth based on comparison with the Bay of Biscay on the Atlantic coast of France (Lesueur et al., 2002) and storm wave base is assumed to have been $\sim 70 \mathrm{~m}$ based on the average values from passive margins provided in Leckie (1987). Given these estimates, the alternation between sharp-based offshore transition-offshore deposits ( $70 \mathrm{~m}$ water depth) and lower shoreface sandstones ( $\sim 30 \mathrm{~m}$ depth) may represent water-depth fluctuations of $\sim 40 \mathrm{~m}-$ a value similar to that suggested by Eyles et al. (1998).

The pronounced flooding surface at the base of the overlying Pebbley Beach Formation marks a bathymetric change of a much higher magnitude than those seen in the Wasp Head Formation. At Depot Beach, the basal Pebbley Beach Formation consists of cyclically interbedded diamictites and laminated offshore mudstones deposited during glacial-interglacial cycles, broadly similar to those described from the Quaternary of east Greenland (Dowdeswell et al., 2000). Given this, and other evidence for late Sakmarian glaciation in eastern Australia (Jones \& Fielding, 2004), the flooding surface at the base of the Pebbley Beach Formation is interpreted as the product of glacioisostatic loading.

This interpretation of the stratigraphic architecture of the Wasp Head Formation differs considerably from the generalized account provided in Eyles et al. (1998), who consider the basal $\sim 50 \mathrm{~m}$ of the Wasp Head Formation to represent an interval that maintained constant water depths during a phase of rapid sedimentation. More significantly, Eyles et al. consider the upper part of the formation to represent shelfal deposits with a series of stacked sharp-based sandstones that record no fewer than six episodes of scouring formed in response to abrupt changes in depositional conditions. Although many of the shore- face sandstones near the top of the formation do have relatively sharp contacts, these beds generally occur within offshore transition deposits and more likely represent relatively unbioturbated storm deposits. No sharp-based sandstones comparable with those formed in response to forced regressions (Posamentier et al., 1992; Posamentier \& Allen, 1999) are present in the Wasp Head Formation. Instead, the three major flooding surfaces in the upper part of the formation represent the only significant changes in paleobathymetry.

\section{Discussion}

The Wasp Head Formation is one of several units in eastern Australia that records a late Asselian to early Sakmarian glacial event in eastern Australia. This glacial event is best preserved in diamictites and varved siltstones within the Boonderoo Beds and Youlambie Conglomerate of Queensland (Jones \& Fielding, 2004). Glacial facies within these formations are restricted to thin, correlative intervals of late Asselian to early Sakmarian age situated between thick successions of distinctly non-glacial strata. The complex facies changes and distribution patterns of these units suggest deposition in association with local, alpine glaciation (Jones \& Fielding, 2004). Initial descriptions of the newly defined Woodton Formation (Kelk, 1986; Roberts et al., 2006) indicate that this upper Asselian to lower Sakmarian unit is probably correlative with the Queensland deposits and also contains dropstones and diamictites. Evidence of this short-lived event is also preserved in glacial deposits in Australia and in the geochemical record of the Pangean paleotropics (Isbell et al., 2003; Montañez et al., 2007; Fielding et al., 2008).

The abundance of locally derived ice-rafted debris in the Wasp Head Formation suggests that coarsegrained sediment was supplied to shoreface and offshore areas by some combination of sea/river ice and the presence of outlet glaciers sourced in nearby uplands (Figure 5). This interpretation represents a simpler alternative to the elaborate model of Eyles et al. (1997) in which those authors invoked icebergs sourced in Antarctica and transported several hundred kilometers along the Panthalassan coastline of Gondwana. This hypothesis was based on the presence of extrabasinal clasts and the assumption that the presence of Glossopteris forests was incompatible with a "severely cold coastline." 
Although it is possible that some of the debris may well have been sourced from distant areas, a regional source is more likely for a number of reasons. Gostin (1968) and the later summary by Gostin \& Herbert (1973) remain the only detailed, published studies of clast composition and provenance for the Wasp Head Formation. In these studies, it is stated that clasts in the lower part of the formation were derived from "local source rocks" and that those in the upper part of the formation were derived from a "varied source area which included granites and acid volcanic rocks at a probable distance of well over $40 \mathrm{~km}$." Although Eyles et al. $(1997,1998)$ invoke an Antarctic contribution above $\sim 40 \mathrm{~m}$ in the Wasp Head Formation, they provide no evidence to support this interpretation. Ice-rafted debris can be carried great distances during Heinrich events (Heinrich, 1988; Hesse \& Khodabakhsh, 1998), but most coarse-grained sediment is deposited within $400 \mathrm{~km}$ of the terminus of an outlet glacier (Drewry, 1986; Benn \& Evans, 1998). Conversely, sea and river ice are capable of transporting large amounts of coarse debris seawards (Lisitzin, 2002). The likely proximity of alpine glaciers is underscored by the presence of diamictites in the overlying Pebbley Beach Formation (Tye et al., 1996; Bann, 1998; Eyles et al., 1998).

Eyles et al. (1997) interpreted the climate of the Sydney Basin at this time as having involved winters that were mild enough to prevent the formation of sea ice and use this interpretation in support of the Antarctic source of glacial debris. The implication of this reasoning is that the presence of forests precludes locally derived ice-rafted debris, but several recent studies demonstrate that the two need not be mutually exclusive. Vegetation capable of surviving in cold, tundra environments had evolved by the Carboniferous (Retallack, 1999a,b) and a variety of plants flourished in high latitude settings by the Permian. Paleobotanical data indicate that conditions were very favorable for plant growth during the summer months (Rayner, 1995) and that glacial deposits and Glossopteris are intimately associated throughout Gondwana (Tye et al., 1996; Smith et al., 1998; Kneller et al., 2004), thus providing strong evidence of coeval glaciers and Glossopteris forests. Perhaps the most compelling evidence of cold-adapted plants comes from the mid-Permian Weller Coal Measures of Antarctica, where Glossopteris forests appear to have formed permafrost-cored palsa mires (Krull, 1999). Given this overwhelming body of evidence, the presence of locally derived ice-rafted de- bris and a favorable climate for plant growth need not be mutually exclusive. Such a setting is, indeed, similar to that observed in the modern coast of southern Alaska where alpine glaciers coexist with high latitude forests.

\section{Conclusions}

Shallow marine strata of the Wasp Head Formation were deposited during the transition to a nonglacial period following the late Asselian to early Sakmarian glaciation in eastern Australia. The basal part of the formation records a gradual deepening upward trend from upper to middle shoreface water depths, a pattern interpreted as recording the transition from glacioisostatic rebound to a subsidence-dominated regime. The upper part of the formation consists of alternations between shoreface and offshore transition-offshore deposits that are organized into three shallowing upward cycles. These sharp-based cycles are interpreted as parasequences formed in response to relatively rapid (glacioeustatic) rises in relative sea-level, or to progradational cycles. Although ice-rafted debris is present throughout the formation, the amount and size of the clasts decrease upwards through the formation. Taken together, the sedimentology and stratigraphic architecture of this unit appear to record the progressive amelioration of climate, decreasing glacial influence and recovery from glacioisostatic rebound that followed an $\sim 8$ Myr glacial event which influenced much of eastern Australia.

The newly redefined upper contact is placed at a regionally traceable transgressive surface that separates the shoreface-offshore transitional deposits of the Wasp Head Formation from the dark, laminated offshore mudstones of the lower Pebbley Beach Formation. This marked transgressive surface probably records glacioisostatic loading and the return of glacial conditions - an interpretation supported by the presence of cyclically interbedded diamictites and dark laminated mudrocks in the lower Pebbley Beach Formation.

The results of this detailed sedimentological and ichnological study provide significant new insight into the depositional environments represented by the Wasp Head Formation-an important first step in constraining the spatial and temporal distribution of glacial ice in eastern Australia during the late Paleozoic. 


\section{Acknowledgments}

This work was supported by NSF Grant EAR-0417578 and the Mr. and Mrs. J. B. Coffman endowment in Sedimentary Geology at the University of NebraskaLincoln. Gary Hampson, Gary Nichols, Peter Haughton, and Paul Carling provided constructive reviews of the manuscript.

\section{References}

Bangert, B., Stollhofen, H., Lorenz, V. and Armstrong, R. (1999) The geochronology and significance of ash-fall tuffs in the glaciogenic Carboniferous-Permian Dwyka Group of Namibia and South Africa. J. Afr. Earth Sci., 29, 33-49.

Bann, K. L. (1998) Ichnology and sequence stratigraphy of the Early Permian Pebbley Beach Formation and Snapper Point Formation in the southern Sydney Basin. Unpublished PhD Thesis, University of Wollongong, Wollongong, New South Wales, 211 pp.

Bann, K. L. and Fielding, C. R. (2004) An integrated ichnological and sedimentological comparison of non-deltaic shoreface and subaqueous delta deposits in Permian reservoir units of Australia. In: The Application of Ichnology to Palaeoenvironmental and Stratigraphic Analysis (Ed. D. McIlroy), Geol. Soc. Spec. Publ., 228, 273-310.

Bann, K. L., Fielding, C. R., MacEachern, J. A. and Tye, S. C. (2004) Differentiation of estuarine and offshore marine deposits using integrated ichnology and sedimentology. In: The Application of Ichnology to Palaeoenvironmental and Stratigraphic Analysis (Ed. D. McIlroy), Geol. Soc. Spec. Publ., 228, 179-211.

Benn, D. I. and Evans, D. J. A. (1998) Glaciers \& Glaciation. Arnold, London, $734 \mathrm{pp}$.

Briggs, D. J. C. (1998) Permian Productidina and Strophalosiidina from the Sydney-Bowen Basin and New England Orogen: Systematics and Biostratigraphic Significance, Vol. 19. Association of Australasian Palaeontologists, Canberra, 258 pp.

Bull, S. W. and Cas, R. A. F. (1989) Volcanic influences in a storm- and tide-dominated shallow marine depositional system: the Late Permian Broughton Formation, southern Sydney Basin, Kiama, N. S. W. Aust. J. Earth Sci., 36, 569-584.

Campbell, K. A., Nesbitt, E. A. and Bourgeois, J. (2006) Signatures of storms, oceanic floods and forearc tectonism in marine shelf strata of the Quinault Formation (Pliocene), Washington, USA. Sedimentology, 53, 945-969.

Carr, P. F., Jones, B. G. and Middleton, R. G. (1989) Precursor and formation of glendonites in the Sydney Basin. Aust. Mineral., 4, 3-13.

Clifton, H. E., Hunter, R. E. and Phillips, R. L. (1971) Depositional structures and processes in the non-barred, high-energy nearshore. J. Sed. Petrol., 41, 651-670.

Crowell, J. C. (1999) Pre-Mesozoic Ice Ages; Their Bearing on Understanding the Climate System . Geol. Soc. Am. Mem., 192, 106 pp.
Crowley, T. J. and Baum, S. K. (1991) Estimating Carboniferous sea-level fluctuations from Gondwanan ice extent. Geology, 19, 975-977.

Crowley, T. J. and Baum, S. K. (1992) Modeling late Palaeozoic glaciation. Geology, 20, 507-510.

Dickins, J. M. (1996) Problems of a Late Palaeozoic glaciation in Australia and subsequent climate in the Permian. Palaeogeogr. Palaeoclimatol. Palaeoecol., 125, 185-197.

Dickins, J. M., Gostin, V. A. and Runnegar, B. (1969) The age of the Permian sequence in the southern part of the Sydney Basin. In: Stratigraphy and Palaeontology, Essays in Honour of Dorothy Hill (Ed. K. S. W. Campbell), pp. 211-255. Australian National University Press, Canberra.

Drewry, D. (1986) Glacial Geologic Processes. Edward Arnold, Baltimore, MD, $276 \mathrm{pp}$.

Eyles, C. H., Eyles, N. and Lagoe, M. B. (1991) The Yakataga Formation; A late Miocene to Pleistocene record of temperate glacial marine sedimentation in the Gulf of Alaska. In: Glacial Marine Sedimentation (Eds. . J. B. Anderson and G. M. Ashley), Geol. Soc. Am. Spec. Pap., 261, 159-180.

Eyles, N., Eyles, C. H. and Gostin, V. A. (1997) Iceberg rafting and scouring in the Early Permian Shoalhaven Group of New South Wales, Australia: evidence of Heinrich-like events. Palaeogeogr. Palaeoclimatol. Palaeoecol., 136, 1-17.

Eyles, C. H., Eyles, N. and Gostin, V. A. (1998) Facies and allostratigraphy of high-latitude, glacially influenced marine strata of the Early Permian southern Sydney Basin, Australia. Sedimentology, 45, 121-161.

Fielding, C. R. and Webb, J. A. (1996) Facies and cyclicity of the Late Permian Bainmedart Coal Measures in the northern Prince Charles Mountains, MacRobertson Land, Antarctica. Sedimentology, 43, 295-322.

Fielding, C. R., Frank, T. D., Birgenheier, L. P., Rygel, M. C., Jones, A. T. and Roberts, J. (2008) Stratigraphic imprint of the Late Paleozoic Ice Age in eastern Australia: a record of alternating glacial and non-glacial climate regime. J. Geol. Soc., 165, 129-140.

Fielding, C. R., Sliwa, R., Holcombe, R. J. and Jones, A. T. (2001) A new palaeogeographic synthesis for the Bowen, Gunnedah and Sydney Basins of eastern Australia. In: PESA Eastern Australasian Basins Symposium, pp. 269278, Melbourne, Victoria.

Fielding, C. R., Bann, K. L., MacEachern, J. A., Tye, S. C. and Jones, B. G. (2006) Cyclicity in the nearshore marine to coastal, Lower Permian, Pebbley Beach Formation, southern Sydney Basin, Australia: a record of relative sea-level fluctuations at the close of the late Palaeozoic Gondwanan ice age. Sedimentology, 53, 435-463.

Forbes, D. L. and Syvitski, J. P. M. (1994) Paraglacial coasts. In: Coastal Evolution (Eds R. W. G. Carter and C. D. Woodroffe), pp. 373-424. Cambridge University Press, New York.

Foster, C. B. and Archbold, N. W. (2001) Chronologic anchor points for the Permian and Early Triassic of the eastern Australian basins. In: Contributions to Geology and Paleontology of Gondwana - In Honour of Helmut Hopfner (Ed. R. E. Weiss), pp. 175-199. Geological Institute, University of Cologne, Cologne.

Frakes, L. A. and Francis, J. E. (1988) A guide to Phanerozoic cold polar climates from high-latitude ice-rafting in the Cretaceous. Nature, 333, 547-549. 
Frakes, L. A., Francis, J. E. and Syktus, J. I. (1992) Climate Modes of the Phanerozoic. Cambridge University Press, Cambridge, 274 pp.

Gingras, M. K., MacEachern, J. A. and Pemberton, S. G. (1998) A comparative analysis of the ichnology of wave- and river-dominated allomembers of the Upper Cretaceous Dunvegan Formation. Bull. Can. Petrol. Geol., 46, 51-73.

Glen, R. A. (2005) The Tasmanides of eastern Australia. In: Terrane Processes at the Margins of Gondwana (Eds A. P. M. Vaughan, P. T. Leat and R. J. Pankhurst), Geol. Soc. Spec. Publ., 246, 23-96.

Gostin, V. A. (1968) Stratigraphy and sedimentology of the Lower Permian sequence in the Durras-Ulladulla area, Sydney Basin, New South Wales. Unpublished PhD Thesis, Australian National University, Canberra, 160 pp.

Gostin, V. A. and Herbert, C. (1973) Stratigraphy of the Upper Carboniferous and Lower Permian sequence, southern Sydney Basin. J. Geol. Soc. Aust., 20, 49-70.

Greenwood, B. and Mittler, P. R. (1985) Vertical sequences and lateral transitions in the facies of a barred nearshore environment. J. Sed. Petrol., 55, 366-375.

Harms, J. C., Southard, J. B., Spearing, D. R. and Walker, R. G. (1975) Depositional environments as interpreted from primary sedimentary structures and stratification sequences. SEPM Short Course Notes, 2, 161.

Heinrich, H. (1988) Origin and consequences of cyclic ice rafting in the northeast Atlantic Ocean during the past 130,000 years. Quatern. Res., 29, 143-152.

Hesse, R. and Khodabakhsh, S. (1998) Depositional facies of late Pleistocene Heinrich events in the Labrador Sea. Geology, 26, 103-106.

Hill, P. R., Barnes, P. W., Héquette, A. and Ruz, M. -H. (1994) Arctic coastal plain shorelines. In: Coastal Evolution (Eds R. W. G. Carter and C. D. Woodroffe), pp. 341-372. Cambridge University Press, New York.

Howard, J. D. and Reineck, H. -E. (1981) Depositional facies of high-energy beach-to-offshore sequence, comparison with low energy sequence. AAPG Bull., 65, 807-830.

Hunter, R. E., Clifton, H. E. and Phillips, R. L. (1979) Depositional processes, sedimentary structures and predicted vertical sequences in barred, nearshore systems, southern Oregon coast. J. Sed. Petrol., 49, 711-726.

Isbell, J. L., Miller, M. F., Wolfe, K. L. and Lenaker, P. A. (2003) Timing of late Palaeozoic glaciation in Gondwana: Was glaciation responsible for the development of Northern Hemisphere cyclothems? In: Extreme Depositional Environments: Mega End Members in Geologic Time (Eds M. A. Chan and A. W. Archer), Geol. Soc. Am. Spec. Pap., 370, 5-24.

Jones, A. T. and Fielding, C. R. (2004) Sedimentological record of the late Palaeozoic glaciation in Queensland, Australia. Geology, 32, 153-156.

Kelk, P. (1986) The stratigraphy and sedimentation of a Late Carboniferous to Early Permian terrestrial-epiclastic sequence $80 \mathrm{~km}$ south of Tamworth, New South Wales. Unpublished BSc Thesis, University of New England, Armidale.

Kneller, B., Milana, J. P., Buckee, C. and al Ja' aidi, O. (2004) A depositional record of deglaciation in a paleofjord (Late Carboniferous [Pennsylvanian] of San Juan Province, Ar- gentina): the role of catastrophic sedimentation. Geol. Soc. Am. Bull., 116, 348-367.

Krull, E. S. (1999) Permian palsa mires as paleoenvironmental proxies. Palaios, 14, 530-544.

Leckie, D. (1987) Wave-formed, coarse-grained ripples and their relationship to hummocky cross-stratification. J. Sed. Petrol., 58, 607-622.

Leithold, E. L. and Bourgeois, J. (1984) Characteristics of coarse-grained sequences deposited in nearshore, wavedominated environments - examples from the Miocene of south-west Oregon. Sedimentology, 31, 749-775.

Lesueur, P., Tastet, J. P. and Weber, O. (2002) Origin and morphosedimentary evolution of fine-grained modern continental shelf deposits: the Gironde mud fields (Bay of Biscay, France). Sedimentology, 49, 1299-1320.

Lever, H. (2004) Cyclic sedimentation in the shallow marine Upper Permian Kennedy Group, Carnarvon Basin, Western Australia. Sed. Geol., 172, 187-209.

Lisitzin, A. P. (2002) Sea-Ice and Iceberg Sedimentation in the Ocean. Springer-Verlag, Heidelberg, 563 pp.

MacEachern, J. A., Bann, K. L., Bhattacharya, J. P. and Howell, C. D., Jr (2005) Ichnology of deltas: organism responses to the dynamic interplay of rivers, waves, storms, and tides. In: River Deltas: Concepts, Models, and Examples (Eds L. Giosan and J. P. Bhattacharya), SEPM Spec. Publ., 83, 49-85.

McCarthy, B. (1979) Trace fossils from a Permian shorefaceforeshore environment, eastern Australia. J. Paleontol., 53, 345-366.

Menning, M., Weyer, D., Drozdzewski, G., van Amerom, H. W. J. and Wendt, I. (2000) A Carboniferous time scale 2000: discussion and use of geological parameters as time indicators from Central and Western Europe. Geol. Jb., 156, 3-44.

Mode, W. N., Nelson, A. R. and Brigham, J. K. (1983) A facies model of Quaternary glacial-marine cyclic sedimentation along eastern Baffin Island, Canada. In: Glacial-Marine Sedimentation (Ed. B. F. Molina), pp. 495-534. Plenum Press, New York.

Molina, B. F. (Ed. ) (1983) Subartic glacial-marine sedimentation: a model. In: Glacial-Marine Sedimentation, pp. 95144. Plenum Press, New York.

Molina, B. F. and Carlson, P. R. (1980) Quaternary sedimentary facies on the continental shelf of the Gulf of Alaska. In: Quaternary Depositional Environments of the Pacific Coast (Eds M. E. Field, A. H. Bouma, I. P. Colburn, R. G. Douglas and J. C. Ingle), SEPM (Pacific Section) Pacific Coast Section Paleogeogr. Symp., 4, 157-168.

Montañez, I. P., Tabor, N. J., Niemeier, D., DiMichele, W. A., Frank, T. D., Fielding, C. R., Isbell, J. L., Birgenheier, L. P. and Rygel, M. C. (2007) $\mathrm{CO}_{2}$-forced climate instability and linkages to tropical vegetation during Late Palaeozoic deglaciation. Science, 315, 87-91.

Phillips, A. C., Smith, N. D. and Powell, R. D. (1991) Laminated sediments in prodeltaic deposits, Glacier Bay, Alaska. In: Glacial Marine Sedimentation; Paleoclimatic Significance (Eds J. B. Anderson and G. M. Ashley), Geol. Soc. Am. Spec. Pap., 261, 51-60.

Posamentier, H. W. and Allen, G. P. (1999) Siliciclastic sequence stratigraphy - concepts and applications. SEPM Concepts Sed. Paleontol., 7, 210. 
Posamentier, H. W., Allen, G. P., James, D. P. and Tesson, M. (1992) Forced regressions in a sequence stratigraphic framework: concepts, examples, and exploration significance. AAPG Bull., 76, 1687-1709.

Rayner, R. J. (1995) The palaeoclimate of the Karoo: evidence from plant fossils. Palaeogeogr. Palaeoclimatol. Palaeoecol., 119, 385-394.

Retallack, G. J. (1999a) Carboniferous fossil plants and soils of an early tundra ecosystem. Palaios, 14, 324-336.

Retallack, G. J. (1999b) Permafrost palaeoclimate of Permian palaeosols in the Gerringong volcanic facies of New South Wales. Aust. J. Earth Sci., 46, 11-22.

Roberts, J., Offler, R. and Fanning, M. (2006) Carboniferous to Lower Permian stratigraphy of the southern Tamworth Belt, southern New England Orogen, Australia: boundary sequences of the Werrie and Rouchel blocks. Aust. J. Earth Sci., 53, 249-284.

Runnegar, B. (1979) Ecology of Eurydesma and Eurydesma fauna, Permian of eastern Australia. Alcheringa, 3, 261-285.

Runnegar, B. (1980) Biostratigraphy of the Shoalhaven Group. Geol. Surv. NSW Bull., 26, 376-382.

Saunders, T. D. A., MacEachern, J. A. and Pemberton, S. G. (1994) Codotte Member Sandstone: progradation in a boreal basin prone to winter storms. In: Manville Core Conference (Eds S. G. Pemberton, D. P. James and M. Wightman), pp. 331-349. Canadian Society of Petroleum Geologists, Calgary, AB.

Smith, N. D., Barrett, P. J. and Woolfe, K. J. (1998) Glacier-fed sandstone sheets in the Weller Coal Measures (Permian), Allan Hills, Antarctica. Palaeogeogr. Palaeoclimatol. Palaeoecol., 141, 35-51.

Stollhofen, H., Stanistreet, I. G., Bangert, B. and Grill, H. (2000) Tuffs, tectonism and glacially-related sea-level changes, Carboniferous-Permian, southern Namibia. Palaeogeogr. Palaeoclimatol. Palaeoecol., 161, 127-150.

Taylor, A. M. and Goldring, R. (1993) Description and analysis of bioturbation and ichnofabric. J. Geol. Soc., 150, 141-148.
Thiele, E. O. (1903) On the occurrence of striated boulders in the Permo-Carboniferous rocks near the mouth of the Shoalhaven River, N. S. W. Proc. Roy. Soc. Victoria, 15, 57.

Thomas, S. G., Frank, T. D. and Fielding, C. R. (2004) Glendonites as paleoclimate indicators within the middle Permian Wandrawandian Siltstone, southern Sydney Basin, Australia. Geol. Soc. Am. Abstr. Programs, 36, 16.

Trapp, E., Kaufmann, B., Mezger, K., Kom, D. and Weyer, D. (2004) Numerical calibration of the Devonian-Carboniferous boundary: two new U-Pb isotope dilution-thermal ionization mass spectrometry single-zircon ages from Hasselbachtal (Sauerland, Germany). Geology, 32, 857-860.

Tye, S. C., Fielding, C. R. and Jones, B. G. (1996) Stratigraphy and sedimentology of the Permian Talaterang and Shoalhaven Groups in the southernmost Sydney Basin, New South Wales. Aust. J. Earth Sci., 43, 57-69.

Veevers, J. J. and Powell, C. M. (1987) Late Palaeozoic glacial episodes in Gondwanaland reflected in transgressive-regressive depositional sequences in Euramerica. Geol. Soc. Am. Bull., 98, 475-487.

Veevers, J. J., Conaghan, P. J. and Powell, C. M. (1994) Eastern Australia. In: Permian-Triassic Pangen Basins and Foldbelts Along the Panthalassan Margin of Gondwanaland (Eds J. J. Veevers and C. M. Powell), Geol. Soc. Am. Mem., 184, 11-171.

Visser, J. N. J. (1997) Deglaciation sequences in the Permo-Carboniferous Karoo and Kalahari basin of southern Africa; a tool in the analysis of cyclic glaciomarine basin fills. Sedimentology, 44, 507-521.

Visser, J. N. J., van Niekerk, B. N. and van der Merwe, S. W. (1997) Sediment transport of the late Palaeozoic glacial Dwyka Group in the southwestern Karoo Basin. S. Afr. J. Geol., 100, 223-236.

Wardlaw, B. R., Davydov, V. and Gradstein, F. M. (2004) The Permian Period. In: A Geologic Time Scale 2004 (Eds F. M. Gradstein, J. G. Ogg and A. G. Smith), pp. 249-270. Cambridge University Press, New York. 